\title{
Education for contraceptive use by women after childbirth (Review)
}

Lopez LM, Hiller JE, Grimes DA, Chen M

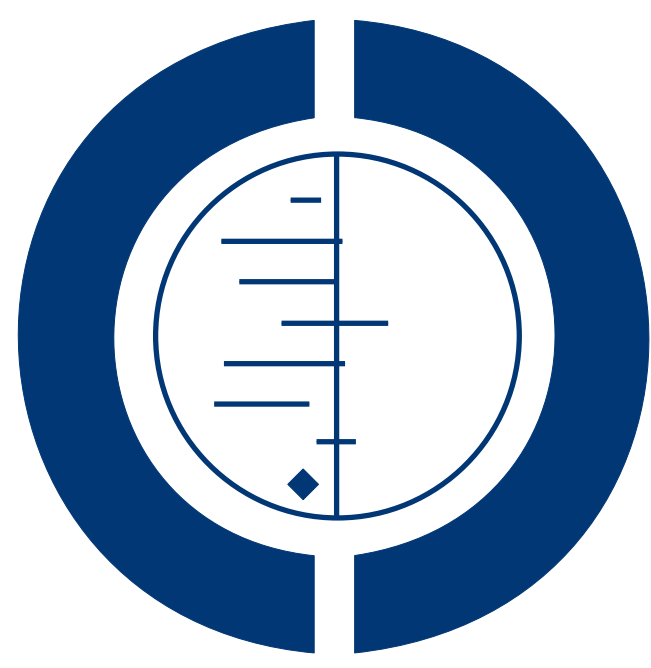

THE COCHRANE
COLLABORATION $^{\circledR}$

This is a reprint of a Cochrane review, prepared and maintained by The Cochrane Collaboration and published in The Cochrane Library 2012, Issue 8

http://www.thecochranelibrary.com

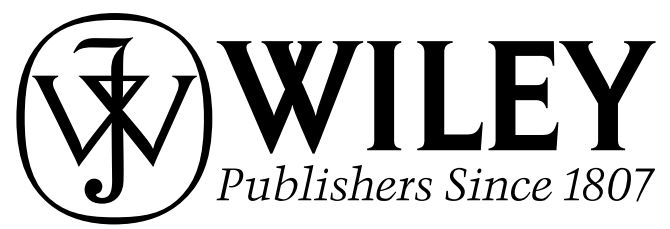

Education for contraceptive use by women after childbirth (Review)

Copyright $\odot 2012$ The Cochrane Collaboration. Published by John Wiley \& Sons, Ltd. 
TABLE OF CONTENTS

HEADER . . . . . . . . . . . . . . . . . . . . . . . . . . . . . . . . . . . . . . . . . . . . .

ABSTRACT . . . . . . . . . . . . . . . . . . . . . . . . . . . . . . . . . . . . . . . . . . . . . . . . . . . . . . .

PLAIN LANGUAGE SUMMARY . . . . . . . . . . . . . . . . . . . . . . . . . . . . . . . . . . . . . . . . . . .

BACKGROUND . . . . . . . . . . . . . . . . . . . . . . . . . . . . . . . . . . . . . 3

OBJECTIVES . . . . . . . . . . . . . . . . . . . . . . . . . . . . . . . . . . . . . . . . . . . . . . . . . . .

METHODS . . . . . . . . . . . . . . . . . . . . . . . . . . . . . . . . . . . . . . . 3

RESULTS . . . . . . . . . . . . . . . . . . . . . . . . . . . . . . . . . . . . . . . . . . . . . .

DISCUSSION . . . . . . . . . . . . . . . . . . . . . . . . . . . . . . . . . . . . . . . . . . . . . . .

AUTHORS' CONCLUSIONS . . . . . . . . . . . . . . . . . . . . . . . . . . . . . . . . . . . . . . . . .

ACKNOWLEDGEMENTS . . . . . . . . . . . . . . . . . . . . . . . . . . . . . . . . . . . . . . . . . . . . . .

REFERENCES . . . . . . . . . . . . . . . . . . . . . . . . . . . . . . . . . . . . . . . . . . . . . . . . .

CHARACTERISTICS OF STUDIES . . . . . . . . . . . . . . . . . . . . . . . . . . . . . . . . . . . . . . . . .

DATA AND ANALYSES . . . . . . . . . . . . . . . . . . . . . . . . . . . . . . . . . . . . . . . . . . . . . . . . . .

Analysis 1.1. Comparison 1 Oral contraceptive education program (one time) versus routine counseling, Outcome 1

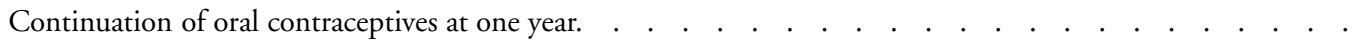

Analysis 1.2. Comparison 1 Oral contraceptive education program (one time) versus routine counseling, Outcome 2 Switched contraceptives by one year. . . . . . . . . . . . . . . . . . . . . . . . . . . .

Analysis 1.3. Comparison 1 Oral contraceptive education program (one time) versus routine counseling, Outcome 3 Known pregnancy by one year. . . . . . . . . . . . . . . . . . . . . . . . . . . . . . . . . . .

Analysis 2.1. Comparison 2 Contraceptive information (one time): physician counseling versus video versus pamphlet, Outcome 1 Satisfied with 'counseling' after the session: video versus physician.

Analysis 2.2. Comparison 2 Contraceptive information (one time): physician counseling versus video versus pamphlet, Outcome 2 Satisfied with 'counseling' after the session: video versus written information. . . . . . . . . . .

Analysis 3.1. Comparison 3 Contraceptive counseling (one time) versus no counseling, Outcome 1 Use of any contraceptive at 8 to 12 weeks postpartum.

Analysis 3.2. Comparison 3 Contraceptive counseling (one time) versus no counseling, Outcome 2 Choice of modern contraceptive (using or plan to use) at 8 to 12 weeks postpartum. . . . . . . . . . . . . . . . . . . . . . . .

Analysis 4.1. Comparison 4 Health education including contraception: immediate, later, and no session, Outcome 1 Use of contraception at 3 months: immediate session versus no immediate session.

Analysis 4.2. Comparison 4 Health education including contraception: immediate, later, and no session, Outcome 2 Use of contraception at 6 months: immediate session versus no immediate session.

Analysis 4.3. Comparison 4 Health education including contraception: immediate, later, and no session, Outcome 3 Use of contraception at 6 months: immediate plus later sessions versus immediate session.

Analysis 4.4. Comparison 4 Health education including contraception: immediate, later, and no session, Outcome 4 Use of contraception at 6 months: later session versus no session.

Analysis 4.5. Comparison 4 Health education including contraception: immediate, later, and no session, Outcome 5 Exclusive breastfeeding at 3 months: immediate session versus no immediate session.

Analysis 4.6. Comparison 4 Health education including contraception: immediate, later, and no session, Outcome 6 Exclusive breastfeeding > 5 months: immediate session versus no immediate session.

Analysis 4.7. Comparison 4 Health education including contraception: immediate, later, and no session, Outcome 7 Exclusive breastfeeding $>=5$ months: immediate and later sessions versus immediate session only. . . . . . .

Analysis 4.8. Comparison 4 Health education including contraception: immediate, later, and no session, Outcome 8 Exclusive breastfeeding $>=5$ months: later session versus no session. $\quad . \quad$. . . . . . . . . . . . . . . . . . . . .

Analysis 5.1. Comparison 5 Special postpartum care (including contraception) versus routine services (multiple well-baby contacts), Outcome 1 Repeat pregnancy (self-report) by 18 months. . . . . . . . . . . . . . . . . . . . .

Analysis 6.1. Comparison 6 Home visiting: structured versus routine, Outcome 1 Effective contraception use at 6 months.

Analysis 7.1. Comparison 7 Home-based mentoring (multiple visits) versus usual care, Outcome 1 Second birth by 24 months.

Analysis 8.1. Comparison 8 Computer-assisted motivational interviewing (CAMI) with parenting curriculum versus CAMI-only versus usual care, Outcome 1 Repeat birth by 24 months. 
Analysis 9.1. Comparison 9 Phone counseling versus usual services, Outcome 1 Repeat pregnancy by 24 months.

Analysis 10.1. Comparison 10 Home visiting: four visits versus one visit versus usual care, Outcome 1 Contraception use at 4 months: 4 visits versus 1 visit.

Analysis 10.2. Comparison 10 Home visiting: four visits versus one visit versus usual care, Outcome 2 Contraception use at 4 months: 1 visit versus usual care.

Analysis 10.3. Comparison 10 Home visiting: four visits versus one visit versus usual care, Outcome 3 Pregnancy (selfreported) at 4 months postpartum: 4 visits versus 1 visit. . . . . . . . . . . . . . . . . . . . . . . . . . .

Analysis 10.4. Comparison 10 Home visiting: four visits versus one visit versus usual care, Outcome 4 Pregnancy (self-

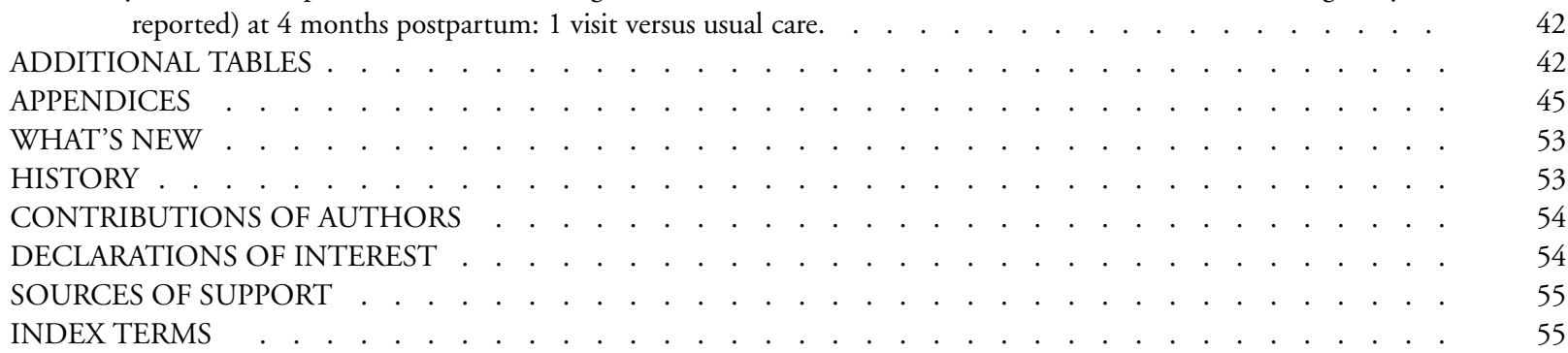

Education for contraceptive use by women after childbirth (Review) 
[Intervention Review]

\title{
Education for contraceptive use by women after childbirth
}

\author{
Laureen M Lopez ${ }^{1}$, Janet E Hiller ${ }^{2}$, David A Grimes ${ }^{3}$, Mario Chen ${ }^{4}$ \\ ${ }^{1}$ Clinical Sciences, FHI 360, Research Triangle Park, North Carolina, USA. ${ }^{2}$ Faculty of Health Sciences, Australian Catholic University, \\ Fitzroy, Australia. ${ }^{3}$ Obstetrics and Gynecology, University of North Carolina, School of Medicine, Chapel Hill, North Carolina, USA. \\ ${ }^{4}$ Division of Biostatistics, FHI 360, Research Triangle Park, North Carolina, USA \\ Contact address: Laureen M Lopez, Clinical Sciences, FHI 360, P.O. Box 13950, Research Triangle Park, North Carolina, 27709, \\ USA. 1lopez@fhi360.org.
}

Editorial group: Cochrane Fertility Regulation Group.

Publication status and date: New search for studies and content updated (no change to conclusions), published in Issue 8, 2012.

Review content assessed as up-to-date: 1 June 2012.

Citation: Lopez LM, Hiller JE, Grimes DA, Chen M. Education for contraceptive use by women after childbirth. Cochrane Database of Systematic Reviews 2012, Issue 8. Art. No.: CD001863. DOI: 10.1002/14651858.CD001863.pub3.

Copyright (C) 2012 The Cochrane Collaboration. Published by John Wiley \& Sons, Ltd.

\begin{abstract}
A B S T R A C T

\section{Background}

Providing contraceptive education is now considered a standard component of postpartum care. The effectiveness is seldom examined. Questions have been raised about the assumptions on which such programs are based, e.g., that postpartum women are motivated to use contraception and that they will not return to a health center for family planning advice. Surveys indicate that women may wish to discuss contraception both prenatally and after hospital discharge. Nonetheless, two-thirds of postpartum women may have unmet needs for contraception. In the USA, many adolescents become pregnant again within a year a giving birth.
\end{abstract}

\section{Objectives}

Assess the effects of educational interventions for postpartum mothers about contraceptive use

\section{Search methods}

In May 2012, we searched the computerized databases of MEDLINE, CENTRAL, CINAHL, PsycINFO, and POPLINE. We also searched for current trials via ClinicalTrials.gov and ICTRP. Previous searches also included EMBASE. In addition, we examined reference lists of relevant articles, and contacted subject experts to locate additional reports.

\section{Selection criteria}

Randomized controlled trials were considered if they evaluated the effectiveness of postpartum education about contraceptive use. The intervention must have started postpartum and have occurred within one month of delivery.

\section{Data collection and analysis}

We assessed for inclusion all titles and abstracts identified during the literature searches with no language limitations. The data were abstracted and entered into RevMan. Studies were examined for methodological quality. For dichotomous outcomes, the MantelHaenszel odds ratio (OR) with $95 \%$ confidence interval (CI) was calculated. For continuous variables, we computed the mean difference (MD) with 95\% CI. Due to varied study designs, we did not conduct meta-analysis.

Education for contraceptive use by women after childbirth (Review)

Copyright $\odot 2012$ The Cochrane Collaboration. Published by John Wiley \& Sons, Ltd. 


\section{Main results}

Ten trials met the inclusion criteria. Of four trials that provided one or two counseling sessions, two showed some evidence of effectiveness. In a study from Nepal, women with an immediate postpartum and a session three months later were more likely to use contraception at six months than those with only the later session (OR 1.62; 95\% CI 1.06 to 2.50). However, most comparisons did not show evidence of effectiveness. In a trial conducted in Pakistan, women in the counseling group were more likely than those without counseling to use contraception at 8 to 12 weeks postpartum (OR 19.56; 95\% CI 11.65 to 32.83). The assessments were short-term. The remaining two studies were from the USA; one did not provided sufficient data and one had too small a sample to detect differences.

Six trials provided multifaceted programs with many contacts. Three showed evidence of effectiveness. Of those, two USA studies focused on adolescents. Adolescents in a home-visiting program were less likely to have a second birth in two years compared to adolescents who received usual care (OR $0.41 ; 95 \%$ CI 0.17 to 1.00$)$. In the other trial, adolescents receiving enhanced well-baby care were less likely to have a repeat pregnancy by 18 months compared to those with usual well-baby care (OR 0.35 ; $95 \%$ CI 0.17 to 0.70$)$. In an Australian study, teenagers in a structured home-visiting program were more likely to use contraception at six months than those who had standard home visits (OR 3.24; 95\% CI 1.35 to 7.79). The trials without evidence of effectiveness included two for adolescents in the USA (computer-assisted motivational interviewing and cell phone counseling) and a home-visiting program for women in Syria.

\section{Authors' conclusions}

The overall quality of evidence was moderate. Half of these postpartum interventions led to fewer repeat pregnancies or births or more contraceptive use. However, the evidence of intervention effectiveness was of low to moderate quality. Trials with evidence of effectiveness included two that provided one or two sessions and three that had multiple contacts. The former had limitations, such as self-reported outcomes and showing no effect for many comparisons. The interventions with multiple sessions were promising but would have to be adapted for other locations and then retested. Researchers and health care providers will have to determine which intervention might be appropriate for their setting and level of resources.

\section{PLAIN LANGUAGE SUMMARY}

\section{Education about family planning for women who have just given birth}

Counseling about family planning is standard care for most women who have just given birth. Many women feel this service is provided as part of a checklist. Few providers and researchers have looked at how well the counseling works. Some people have questioned the basis for such programs. We do not know if postpartum women want to use family planning or whether they will return to a health center for family planning advice. Women may wish to discuss family planning before they have the baby and after they leave the hospital. Women may also prefer to talk about birth control along with other health issues. In this review, we looked at the effects of educational programs about family planning for women who have just had a baby.

In May 2012, we did computer searches to find trials of education about family planning after having a baby. We also wrote to researchers to find other trials. The trials had to study how much the program affected family planning use. The program must have occurred within a month after the birth. We had no language limits for the searches. We entered the data into RevMan and used the odds ratio to examine effect. We also looked at the quality of the research methods.

We found 10 trials. Of four trials with one two contacts, two gave the women education while in the hospital. One showed more women in the counseling group used birth control than those without counseling at 8 to 12 weeks. In the other, more women with counseling both right after birth and later used birth control at six months than those with only the later session. Of the other two trials, one did not have enough data and the other was a very small study. Three of six trials with longer and more complex programs made a difference. Two showed fewer pregnancies or births among teenagers in the group with extra services. Also, a special homevisiting program showed more birth control use.

The overall results were of moderate quality. However, the five studies that showed some effect were low to moderate quality. These programs would have to be adapted for other settings and then retested. Researchers and health care providers can decide which ones might fit their setting and budget.

Education for contraceptive use by women after childbirth (Review)

Copyright $\odot 2012$ The Cochrane Collaboration. Published by John Wiley \& Sons, Ltd. 


\section{B A C K G R O U N D}

The provision of contraceptive education is now considered a standard component of postpartum care. Education is frequently provided as part of discharge planning, but many women experience a perfunctory discussion in a checklist of topics (Glasier 1996). Midwifery and obstetric texts routinely refer to the provision of such education as a responsibility in postpartum care, but the effectiveness is seldom questioned (Keith 1980; Semeraro 1996). Postpartum contraception counseling is often limited to one encounter, which is unlikely to affect behavior. Decisions about contraception made right after counseling may differ considerably from contraceptive use postpartum (Engin-Üstün 2007). As common as postpartum contraceptive education has become, research evaluating such interventions is still sparse (FHI 2009; Glazer 2011). We know more about contraceptive methods appropriate for postpartum women (Shaw 2007; FHI 2009) than we do about how to help postpartum women choose and use a contraceptive.

In 1966, the Population Council sponsored demonstration projects on postpartum family planning, focusing primarily on developing countries, and including 25 hospitals in 14 countries (Zatuchni 1970). These projects were based on the assumptions that women are receptive to family planning education in the postpartum period, and that they will not return to health centers for contraception once they have been discharged from hospital. The demonstration projects were declared a success given their ability to reach large numbers of women, and they were expanded to include hospitals in 21 countries (Winikoff 1991). Randomized controlled trials were not used to assess the effectiveness of the program.

Demographic and Health Surveys indicate that nearly two-thirds of women in their first postpartum year have an unmet need for family planning (Ross 2001; USAID 2012). Data from 17 countries show that return to sexual activity is associated with the return of menses, breastfeeding status, and postpartum duration but not generally associated with contraceptive use (Borda 2010). In the USA, adolescents often have repeat pregnancies within a year of giving birth (Thurman 2007). While adolescents may start using contraception during the postpartum period, they often discontinue due to lack of information or support (Wilson 2011).

Postpartum women may wish to discuss contraception prenatally or after hospital discharge, preferably in the context of general education about maternal and child health (Glasier 1996; Ozvaris 1997). Many women are comfortable with advice and a prescription from their physician during well-baby visits (Fagan 2009). The Matlab project examined the impact of providing experimental maternal and child health and family planning programs in a rural area in Bangladesh; intensive provision of family planning services resulted in increased uptake of contraceptives (Koenig 1992). A current trial is studying the effect on contraceptive use from integrating family planning into infant immunization services (Dulli 2010). This review examines randomized controlled trials of postpartum interventions to educate women about contraceptive choices.

\section{O B J E C T IVES}

Primary objective was to determine the effectiveness of educational interventions for postpartum mothers about contraceptive use. Effects include unplanned pregnancies; contraceptive knowledge, attitudes, and practices; breast feeding behavior; and satisfaction with care.

Secondary objective was to determine the effectiveness of the interventions according to the following:

- Mode of delivery (pamphlet or other written material, video or audio recording, one-to-one or group counseling);

- Type of health professional providing the intervention (midwife or nurse, physician, or specially trained lay person);

- Timing (immediately postpartum, postpartum visit in a health care facility or at home, or another occasion).

\section{METHOD S}

\section{Criteria for considering studies for this review}

\section{Types of studies}

Randomized controlled trials (RCTs) were considered if they examined postpartum education about contraceptive use, whether delivered to individuals or to groups of women. We excluded trials focused on the needs of women with alcohol or drug problems and trials focused on women with chronic health conditions such as HIV or diabetes.

\section{Types of participants}

All women giving birth at 20 weeks' gestation or more.

\section{Types of interventions}

Trials were included if they evaluated postpartum education provided to influence uptake of contraception including lactational amenorrhea. Educational interventions may have been based on written materials, video or audio recordings, or individual or group counseling. The intervention must have started postpartum and occurred within one month of delivery. 


\section{Types of outcome measures}

\section{Primary outcomes}

The main outcomes of interest were unplanned pregnancies and choice or use of contraception. Trials had to have one of these outcomes to be included in this review.

\section{Secondary outcomes}

Additional outcomes included knowledge about contraception, breast feeding, and satisfaction with postnatal care.

\section{Search methods for identification of studies}

\section{Electronic searches}

In May 2012, we conducted searches of MEDLINE, Cochrane Central Register of Controlled Trials (CENTRAL), POPLINE, CINAHL, and PsycINFO. We also searched for current trials via ClinicalTrials.gov and ICTRP. The search strategies are given in Appendix 1. Previous search strategies also included EMBASE and are shown in Appendix 2 and Appendix 3.

\section{Searching other resources}

Reference lists of relevant papers were examined for additional citations. We also contacted investigators in the field to seek unpublished trials or published trials we may have missed in our searches. For the initial review, the following organizations were contacted requesting advice about relevant research: Guttmacher Institute, California Family Health Council, Contraceptive Research and Development, Couple to Couple League, Engender Health, European Commission, Health, Family Planning and AIDS Unit, Family Planning Association of Queensland, Family Planning Councils of America, Family Planning International Assistance, Family Planning Management Development, Healthy Women, Johns Hopkins University Center for Communication Programs, Marie Stopes International, National Family Planning and Reproductive Health Association, Planned Parenthood Global Partners, Population and Community Development Association, Population Reference Bureau, Prime II, Program of Appropriate Technology in Health.

For the original review, the authors also searched databases listing publications by the Population Council, Family Health International, and the World Health Organization.

\section{Data collection and analysis}

\section{Selection of studies}

For the initial review, the three authors independently assessed the studies to determine which were suitable for inclusion in the review. In the event of disagreement, the authors resolved the differences by discussion. For the 2009 and 2012 updates, one author reviewed the search results. A second author examined the reports identified for appropriate categorization. We excluded studies that appeared to randomize clusters rather than individuals and did not account for the clustering in the analysis.

\section{Data extraction and management}

One author abstracted the data and entered the information into RevMan. A second author or staff person conducted the secondary data abstraction and verified correct data entry. Any discrepancies were resolved by discussion.

We used the framework in Borrelli 2005 to extract information on the intervention. The categories most pertinent to this work were in the intervention design, i.e., treatment dose for both experimental and comparison groups, and information on implementation fidelity (e.g., training of providers and quality assurance. The dose information is similar to what is usually extracted for pharmacologic interventions, such as the length and number of sessions (rather than pills), the content, and the duration of contacts. Consequently, the 'dose' information is shown in the Characteristics of included studies. Information on implementation fidelity is shown in Table 3 if provided in the trial report.

\section{Assessment of risk of bias in included studies}

Included trials were evaluated for methodological quality in accordance with recommended principles (Higgins 2011). Factors considered included randomization method, allocation concealment, blinding, and losses to follow-up and early discontinuation. This information was entered into the Risk of bias tables (Characteristics of included studies).

\section{Measures of treatment effect}

For the dichotomous outcomes, the Mantel-Haenszel odds ratio (OR) with 95\% confidence interval (CI) was calculated using a fixed-effect model. An example is the proportion of women who initiated use of a particular contraceptive method. Fixed and random effects give the same result if no heterogeneity exists, as when a comparison includes only one study. For continuous variables, the mean difference (MD) was computed with $95 \%$ CI using a fixed effect model. RevMan uses the inverse variance approach. Due to varied study designs, we did not conduct any meta-analysis.

\section{Assessment of heterogeneity}

Due to varied study designs, we were unable to conduct metaanalysis. Therefore, we did not need to assess statistical hetero- 
geneity. However, we address heterogeneity due to differences in interventions, study design, and populations in the Discussion.

\section{Data synthesis}

We applied principles from GRADE to assess the quality of evidence and address confidence in the effect estimates (Balshem 2011). We did not intend to conduct a formal GRADE assessment, i.e., with an evidence profile and summary of findings table (Guyatt 2011). When a meta-analysis is not viable, as in this review due to varied interventions, a summary of findings table is not feasible.

We had two levels for assessment, both of which were developed post hoc. First we assessed the quality of the intervention design, implementation, and reporting. We downgraded studies for each of the following: a) fewer than two sessions provided; b) intervention fidelity information reported for fewer than three items (Table 3); c) follow-up was less than six months. We incorporated quality of intervention evidence (Table 1) into the overall assessment of evidence quality (Table 2 ). We considered RCTs to be high quality then downgraded a level for each of the following: a) no information on randomization sequence generation or allocation concealment, or no allocation concealment; b) low intervention quality; c) outcome assessment (no objective assessment, e.g., pregnancy test, or no structured questionnaire for contraceptive use); d) losses to follow-up greater than $20 \%$; e) other (selective outcome reporting or exclusions after randomization). We upgraded one level if some blinding was used. Due to the types of interventions, blinding of investigators and participants to assignment would be difficult, although blinding of outcome assessors was more feasible. We included evidence of intervention effectiveness to compare evidence quality with results. Our assessment of the body of evidence is based on the quality of evidence from the studies.

\section{RE S U L T S}

\section{Description of studies}

See: Characteristics of included studies; Characteristics of excluded studies; Characteristics of ongoing studies.

\section{Results of the search}

The 2012 search produced 217 new references. After reviewing the titles and abstracts, 212 were discarded due to not meeting the Criteria for considering studies for this review. We examined the full text of five reports; two were later excluded. Three reports from two trials were added to the eight trials included in earlier versions of this review. In addition, we included two ongoing trials identified in clinical trials databases.

\section{Included studies}

Ten trials met our inclusion criteria. A total of 3505 women participated in these trials, ranging from 33 to 904 per trial (median $=246$ ). Six studies were conducted in the USA and one was done in each of Australia, Nepal, Pakistan, and Syria. Five trials focused on adolescents (Barnet 2009; Black 2006; Katz 2011; O’Sullivan 1992; Quinlivan 2003) and one on young women (Gilliam 2004), while the other four did not have age limits.

The studies varied in the content and format of the education provided.

- Three trials focused on contraception and provided one session prior to discharge. In Saeed 2008, the control had no educational intervention. The other two trials had routine or alternative care as the comparison (Gilliam 2004; Proctor 2006).

- Seven trials addressed broader health education or parenting issues as well as contraception. These studies involved the following: multiple home visits (Barnet 2009; Bashour 2008; Black 2006; Quinlivan 2003), multiple clinic contacts (O’Sullivan 1992), and multiple phone sessions (Katz 2011). One trial provided a session in the hospital and another contact at home (Bolam 1998); one study arm had no health education.

All reports had some information regarding intervention fidelity (Table 3). In most trials, clinicians provided the education and had some intervention training although the intensity of training varied. In a few studies, the women who provided the intervention had demographics similar to those of the participants. All reports had information on the intervention content or its development. Outcomes included pregnancy and contraceptive use. Six trials reported on repeat pregnancy or second birth. Six assessed contraceptive use, but only five had data for analysis in this review. Only Proctor 2006 did not have any follow-up after discharge.

\section{Risk of bias in included studies}

\section{Allocation}

Five trials provided information on sequence generation and used sealed envelopes to conceal the allocation (Bashour 2008; Bolam 1998; Gilliam 2004; Proctor 2006; Quinlivan 2003). Three had information on the randomization procedure but nothing on allocation concealment (Barnet 2009; Katz 2011; Saeed 2008). Two provided no information on sequence generation or concealment (Black 2006; O’Sullivan 1992).

\section{Blinding}

Blinding of assignment was not possible in most trials, given the nature of the interventions. However, the outcome assessors were blind to group of allocation in three trials (Bashour 2008; 
Bolam 1998; Saeed 2008). Research team members were reportedly blinded in Gilliam 2004. The other six trials had no information on blinding.

\section{Incomplete outcome data}

Losses to follow-up were greater than $20 \%$ in two trials: Bolam 1998 (25\% at three months and 27\% at six months) and Gilliam 2004 ( $52 \%$ by one year).

\section{Other potential sources of bias}

Two trials excluded participants after randomization due to missing data (Black 2006; Proctor 2006). In addition, Barnet 2009 excluded one with a stillborn infant and one whose two-month old infant died.

Proctor 2006 reported the primary outcome was satisfaction. However, the researchers only used one dichotomous item to assess satisfaction, thus limiting the validity and reliability of the assessment.

\section{Effects of interventions}

\section{Counseling (one or two contacts)}

Three trials provided a single counseling session focused on contraception (Gilliam 2004; Proctor 2006; Saeed 2008). A fourth covered a broader range of health education issues in one or two sessions (Bolam 1998).

In Gilliam 2004, the experimental and comparison groups were not significantly different in the proportions that continued oral contraceptive use at one year (Analysis 1.1), those who switched the type of contraceptive used (Analysis 1.2), or known pregnancies (Analysis 1.3). The sample size was too small to detect differences with adequate power.

Proctor 2006 reported satisfaction with the counseling, but the results were limited due to a one-item dichotomous scale. Women who had counseling from a physician were more likely to be satisfied than those who watched a video (OR 0.27; 95\% CI 0.07 to 0.98 ) (Analysis 2.1). The satisfaction of the video watchers was not significantly different from that of the pamphlet-receivers (Analysis 2.2). The researchers also examined contraceptive choice prior to discharge, but presented the results in a graph without specific numbers. Reportedly, the study groups were not significantly different in their choices of contraceptive method.

At 8 to 12 weeks postpartum in Saeed 2008, women in the counseling group were more likely to report using contraception (OR 19.56; 95\% CI 11.65 to 32.83) (Analysis 3.1). For choice of contraceptive, all women in the counseling group planned to use a modern contraceptive method by six months postpartum compared to a third of the control group (OR 1038.09; 95\% CI 64.15 to 6799.73) (Analysis 3.2). The wide 95\% CI might be related to the women in the intervention group providing the socially desirable response, although the physician-assessor was reportedly blinded to study arm.

Bolam 1998 provided up to two health education sessions, depending on the study arm. Two of the four study groups had health education during their postpartum hospital stay. One of those two had a second session at three months, which included family planning. A third arm had the educational session at three months, and a fourth received no health education (Types of interventions). We first grouped those with a health education session during their postpartum hospital stay and those without such an immediate session. The groups did not differ significantly at three months (Analysis 4.1). At six months, the group with the immediate postpartum session was more likely to use contraception than the group with no immediate session (OR 1.62; 95\% CI 1.06 to 2.50) (Analysis 4.2). We also compared the arms within the larger groups at six months (three-month data were not available). The group with two sessions did not differ significantly in contraceptive use from the group with one immediate session (Analysis 4.3). Also, contraceptive use in the group with only the later session was not significantly different from the group with no educational session (Analysis 4.4). Exclusive breastfeeding was emphasized in the immediate postpartum session. The study arms did not differ significantly in exclusive breastfeeding in any of the comparisons (Analysis 4.5 to Analysis 4.8).

\section{Programs with multiple contacts (home, phone, or clinic)}

All six trials provided interventions that covered a range of health and lifestyle issues, including contraception. Five studies targeted adolescents; four were conducted in the eastern USA (O'Sullivan 1992; Black 2006; Barnet 2009; Katz 2011) and one in Australia (Quinlivan 2003). Bashour 2008, which was conducted in Syria, did not focus on a specific age group.

- In O'Sullivan 1992, the experimental group had special services provided within the well-baby clinic, including reminder contacts. The comparison group had the usual well-baby care. The teenagers in the experimental group were less likely to have a repeat pregnancy (self-reported) by 18 months compared to the control group (OR 0.35; 95\% CI 0.17 to 0.70 ) (Analysis 5.1). The difference in pregnancies was largely within the subgroup of clinic dropouts. Of the control group, 29/91 had a repeat pregnancy versus 9/60 in the experimental group (data not shown).

- For Quinlivan 2003, young women in the experimental group were more likely to have effective contraceptive use at six months than the comparison group (OR 3.24; 95\% CI 1.35 to 7.79) (Analysis 6.1). Women in the experimental group had a structured home-visiting program as opposed to standard home visits. We did not have sufficient data to analyze contraceptive knowledge in this review. Reportedly, the mean difference in 
contraceptive knowledge at six months favored the experimental group (reported MD 0.92; 95\% CI 0.32 to 1.52 ).

- Black 2006 evaluated second births during home visits. The experimental group had multiple home visits over two years, while the controls had usual care. The mean number of intervention visits was 6.63 (standard deviation 6.58). The adolescents in the treatment group were less likely to have had a second birth within two years than the usual care group (OR $0.41 ; 95 \%$ CI 0.17 to 1.00 ) (Analysis 7.1 ).

- The study groups in Barnet 2009 did not differ significantly for repeat births by 24 months from index birth (Analysis 8.1). Births were assessed through Vital Statistics; $100 \%$ of the index births were located. While the repeat birth rates for both CAMI groups were lower than, but not significantly different from, the rate for the usual care group. The figures were $13.8 \%$ for CAMI plus parenting curriculum (CAMI+), 17.2\% for CAMI-only, and $25 \%$ for usual care. Abortion information was obtained at the follow-up interview. The researchers communicated that the percentages for reported abortions were as follows: CAMI+ $22 \%$, CAMI-only $20 \%$, and usual care $21 \%$.

- Katz 2011 assessed subsequent pregnancy via cell phone calls at 3, 9, 15, and 21 months. Pregnancy status was confirmed by urine pregnancy tests at $6,12,18$ and 24 months. Pregnancy rates did not differ significantly between the study groups during the two-year follow-up (Analysis 9.1). The rates were 31\% for the group with the cell phone intervention and $36 \%$ for the usual care group.

Bashour 2008 did not focus on a specific age group. At four months, the study groups did not differ significantly in contraceptive use (Analysis 10.1; Analysis 10.2) or self-reported pregnancy (Analysis 10.3; Analysis 10.4). The experimental group had up to four home visits, with the last one focusing on family planning. One study group had a single visit without family planning and the control group had usual care, which did not include a home visit.

\section{DISCUSSION}

\section{Summary of main results}

Of the four interventions with one or two sessions, one trial had too small a sample to detect differences with adequate power (Gilliam 2004), and one did not have sufficient data on contraceptive use for analysis here (Proctor 2006). The remaining two showed some evidence of effect on contraceptive use (Bolam 1998; Saeed 2008). The experimental groups had some counseling in the immediate postpartum period while the comparison group did not. These outcome measures were based on self-report. In addition, in Bolam
1998, one of four contraceptive outcome measures showed a positive effect, and the groups did not differ significantly for the exclusive breastfeeding comparisons. For Saeed 2008, use of contraception was only assessed at 8 to 12 weeks.

Of the six programs with multiple contacts, three showed some evidence of effect on pregnancy or contraceptive use. Family planning education was integrated with other health education or health services. Of five that focused on adolescents, two showed fewer repeat pregnancies or second births within the experimental group (Black 2006; O'Sullivan 1992). The experimental groups had enhanced services compared to the controls. Black 2006 assessed second births during home visits, while O'Sullivan 1992 used self-report in clinic. In O'Sullivan 1992, the researchers assessed other outcomes with independent sources, such as school attendance (for the teenager returning to school) and child immunization via chart audits. In Quinlivan 2003, the structured homevisiting program for teen mothers favored contraceptive use in the experimental group. The control group had standard home visits. The researchers attempted to verify self-reports against an independent source, including pill packets and prescriptions (clinic or physician). Of the other three trials that did not show evidence of effectiveness, two focused on adolescents (Barnet 2009; Katz 2011) while one did not have any age limits (Bashour 2008).

Two studies addressed costs (Barnet 2009; O’Sullivan 1992). In O'Sullivan 1992, both groups received well-baby care in the clinic. The hospital estimated the cost per visit to be lower for special care than routine care. The savings were attributed to several factors, such as combining services and not using medical residents who would need training and faculty supervision. In a 2010 article from Barnet 2009, the reported weighted mean costs for any CAMI were US \$2064 per teen. Costs per teen were US \$1449 for CAMIonly and US \$2635 for CAMI + parenting curriculum.

\section{Overall completeness and applicability of evidence}

The included trials represented various types of postpartum educational interventions: one or two sessions and multiple-contact programs in four countries. Several interventions were provided during the postpartum hospital stay, while others began two or three weeks later. Unfortunately, two trials did not contribute much to this review, given insufficient data or an inadequate sample size. Of the five trials showing positive effects, two were conducted in the USA and the others were from Australia, Nepal, and Pakistan. We did not examine interventions focused on postpartum contraception that began during the prenatal period.

\section{Quality of the evidence}

All reports provided some documentation of intervention content and most had implementation information (Table 3). A few did 
not provide much or any information on training of providers for the specific intervention. Only three reported on how the researchers assessed delivery adherence, i.e., whether the intervention was provided as intended. The intervention evidence was high or moderate quality for eight studies (Table 1). Four trials provided only one or two educational sessions, generally in the hospital setting. Three had limited follow-up of less than six months.

In terms of research design and implementation, five trials had some allocation concealment. Only one early study had no information on either generation of the randomization sequence or allocation concealment. Four mentioned some type of blinding, usually of the assessors. Outcome assessment was limited in several studies. That is, three of six trials that assessed pregnancies or repeat births had some objective validation. However, some studies assessed or reported contraceptive use with one dichotomous item. Two trials had high losses to follow-up. However, losses to follow-up were not as high overall as some trials in contraceptive education (Lopez 2011). The short-term nature of several interventions or the follow-up period may have limited losses in some cases but may also have limited the measures of effectiveness.

The overall quality of evidence was moderate (Table 2) due to having six studies that provided moderate or high quality evidence and four of low or very low quality. Most of the trials were published since the 2001 CONSORT guidelines (CONSORT 2009), and would be expected to have adequate reporting. However, only two of the six trials with moderate or high quality evidence showed any intervention effectiveness. The other evidence of effectiveness came from three trials of low or very low quality. Consequently, the evidence of effect was of low to moderate quality.

\section{A U THORS' CONCLUSIONS}

\section{Implications for practice}

Half of these interventions led to fewer unplanned pregnancies or more contraceptive use. The interventions that showed some effectiveness included two with one or two sessions and three with mul- tiple contacts. The former were limited by self-reported outcomes or showing no effect for many comparisons. The programs involving multiple contacts showed promise but would need adapting for other locations and then retesting. Health care providers would have to decide which intervention might be appropriate for their setting and level of resources.

\section{Implications for research}

The overall quality of evidence was moderate. However, the evidence of intervention effectiveness was of low to moderate quality. The interventions with one or two sessions often had self-reported outcomes or short-term assessments or showed no evidence of effect for many comparisons. Researchers should validate outcome measures and then examine different short-term interventions in randomized trials. The longer-term interventions were promising, and some researchers verified self-report with other sources. However, the programs have to be adapted for other situations and resources and then retested.

\section{ACK NOW LEDGEMENTS}

M Gulmezoglu of WHO extracted data from Nacar 2003, which was published in Turkish. From FHI 360, C Manion searched the electronic databases.

The original Cochrane Review was an update of a pre-Cochrane review (Hay-Smith 1994). The original authors acknowledge the assistance provided by A Lusher of the Oxford Cochrane Centre in developing the search strategy for the 2002 update, the assistance provided by V Kallianes and B Winikoff of the Population Council in identifying research on this topic for the 1999 version of the review, and the support provided by the Cochrane Health Promotion and Public Health Field.

For the 2012 update, S Mullins of FHI 360 helped review search results. She also conducted the second data abstraction for the new trials.

\section{R E F E R E N C E S}

\section{References to studies included in this review}

Barnet 2009 \{published data only\}

* Barnet B, Liu J, DeVoe M, Duggan AK, Gold MA, Pecukonis E. Motivational intervention to reduce rapid subsequent births to adolescent mothers: a communitybased randomized trial. Annals of Family Medicine 2009, issue 5:436-45.

Barnet B, Rapp T, DeVoe M, Mullins CD. Costeffectiveness of a motivational intervention to reduce rapid repeated childbearing in high-risk adolescent mothers: a rebirth of economic and policy considerations. Archives of Pediatrics \& Adolescent Medicine 2010; Vol. 164, issue 4: 370-6.

Bashour 2008 \{published data only\}

Bashour HN, Kharouf MH, Abdulsalam AA, El Asmar K, Tabbaa MA, Cheikha SA. Effect of postnatal home visits on maternal/infant outcomes in Syria: a randomized controlled trial. Public Health Nursing 2008;25(2):115-25.

Black 2006 \{published data only (unpublished sought but not used)\} Black MM, Bentley ME, Papas MA, Oberlander S, Teti LO, 
McNary S, et al.Delaying second births among adolescent mothers: a randomized, controlled trial of a home-based mentoring program. Pediatrics 2006;118(4):e1087-99. Black MM, Siegel EH, Abel Y, Bentley ME. Home and videotape intervention delays early complementary feeding among adolescent mothers. Pediatrics 2001;107:e67.

Bolam 1998 \{published data only\}

* Bolam A, Manandhar DS, Shreshtha P, Ellis M, Costello AM. The effects of postnatal health education for mothers on infant care and family planning practices in Nepal: a randomised controlled trial. British Medical Journal 1998; 316:805-11.

Gilliam 2004 \{published data only\} Gilliam M, Knight S, McCarthy M. Success with oral contraceptives: a pilot study. Contraception 2004;69:413-8.

Katz 2011 \{published data only\}

Katz KS, Rodan M, Milligan R, Tan S, Courtney L, Gantz $\mathrm{M}$, et al.Efficacy of a randomized cell phonebased counseling intervention in postponing subsequent pregnancy among teen mothers. Maternal and Child Health Journal. Germany: Springer, 2011; Vol. 15, issue Suppl 1: S42-53.

O'Sullivan 1992 \{published data only\}

O'Sullivan AL, Jacobsen BS. A randomized trial of a health care program for first-time adolescent mothers and their infants. Nursing Research 1992;41:210-5.

Proctor 2006 \{published data only (unpublished sought but not used)\} Proctor A, Jenkins TR, Loeb T, Elliot M, Ryan A. Patient satisfaction with 3 methods of postpartum contraceptive counselling. A randomized, prospective trial. Journal of Reproductive Medicine 2006;51:377-82.

Quinlivan 2003 \{published data only\} Quinlivan JA Box H, Evans SF. Postnatal home visits in teenage mothers: a randomised controlled trial. Lancet 2003;361:893-900.

Saeed 2008 \{published data only\} Saeed GA, Fakhar S, Rahim F, Tabassum S. Change in trend of contraceptive uptake--effect of educational leaflets and counseling. Contraception 2008;77(5):377-81.

\section{References to studies excluded from this review}

Barnet 2007 \{published data only\}

Barnet B, Liu J, DeVoe M, Alperovitz-Bichell K, Duggan AK. Home visiting for adolescent mothers: effects on parenting, maternal life course, and primary care linkage. Annals of Family Medicine 2007;5:224-32.

Christie 2011 \{published data only\}

Christie J, Bunting B. The effect of health visitors' postpartum home visit frequency on first-time mothers: cluster randomised trial. International journal of nursing studies 2011, issue 6:689-702.

El-Kamary 2004 \{published data only\} El-Kamary SS, Higman SM, Fuddy L, McFarlane E, Sia C, Duggan AK. Hawaii's healthy start home visiting program: determinants and impact of rapid repeat birth. Pediatrics 2004;114:e317-26.

Foreit 1993 \{published data only (unpublished sought but not used)\} Foreit KG, Foreit JR, Lagos G, Guzman A. Effectiveness and cost effectiveness of postpartum IUD insertion in Lima, Peru. International Family Planning Perspectives 1993;19: 19-24.

Guzman A, Lagos G, Herrera J, Foreit JR. Immediate postpartum and post-abortion family planning program.. Final Report. Profamilia and Instituto Peruano del Seguro Social (IPSS). (Project supported by the Population Council and funded by the US Agency for International Development, Office of Population, under contract number AID/DPE3030-000-4074-00, Operations Research to Improve Family Planning Maternal-Child Health Services Delivery Systems in Latin America and the Caribbean (INOPAL) 1990.

Lee 2007 \{published data only\}

Lee JT Yen HW. Randomized controlled evaluation of a theory-based postpartum sexual health education programme. Journal of Advanced Nursing 2007;60: 389-401.

\section{Lee 2011 \{published data only\}}

Lee JT, Tsai JL, Tsou TS, Chen MC. Effectiveness of a theory-based postpartum sexual health education program on women's contraceptive use: a randomized controlled trial. Contraception. 2011/06/15 2011; Vol. 84, issue 1: $48-56$.

Nacar 2003 \{published data only\}

Nacar M Ozturk A, Ozturk Y. [The effect of family planning education given during postpartum period on the use of contraceptive methods]. Erciyes Tip Dergisi 2003;25: $122-30$.

Norr 2003 \{published data only\}

Norr KF, Crittenden KS, Lehrer EL, Reyes O, Boyd CB, Nacion KW, et al.Maternal and infant outcomes at one year for a nurse-health advocate home visiting program serving African Americans and Mexican Americans. Public Health Nursing 2003;20:190-203.

Olds 2002 \{published data only\}

Olds DL, Robinson J, O’Brien R, Luckey DW, Pettitt LM, Henderson CR Jr, et al.Home visiting by paraprofessionals and by nurses: a randomized, controlled trial. Pediatrics 2002;110:486-96.

Olds DL, Robinson J, Pettitt L, Luckey DW, Holmberg J, $\mathrm{Ng}$ RK, et al.Effects of home visits by paraprofessionals and by nurses: age 4 follow-up results of a randomized trial. Pediatrics 2004;114:1560-8.

Omu 1989 \{published data only\}

Omu AE, Weir SS, Janowitz B, Covington DL, Lamptey PR, Burton NN. The effect of counseling on sterilization acceptance by high-parity women in Nigeria. International Family Planning Perspectives 1989;15:66-71.

Ransjo-Arvidson 1998 \{published data only\}

Ransjö-Arvidson AB, Chintu K, Ng'andu N, Eriksson B, Susu B, Christensson K, et al.Maternal and infant health 
problems after normal childbirth: a randomised controlled study in Zambia. Journal of Epidemiology and Community Health 1998;52:385-91.

\section{Sayegh 1976 \{published data only\}}

Sayegh J, Mosley WH. The effectiveness of family planning education on acceptance of contraception by postpartum mothers. Johns Hopkins Medical Journal 1976;139(Suppl): $31-7$.

\section{Smith 2002 \{published data only\}} Smith KB, van der Spuy ZM, Cheng L, Elton R, Glasier $A F$. Is postpartum contraceptive advice given antenatally of value?. Contraception 2002;65:237-43.

\section{References to ongoing studies}

\section{Dulli 2010 \{published data only\}}

Dulli L. Postpartum family planning service through enhanced family planning in immunization services (PPFPIZ). http://clinicaltrials.gov/ct2/show/NCT01115361 (accessed 07 Apr 2012). [: NCT01115361]

\section{Sadler 2011 \{published data only\}}

Sadler L. Minding the baby home visiting: program evaluation. http://clinicaltrials.gov/ct2/show/ NCT01115361 (accessed 07 Apr 2012). [: NCT01115361]

\section{Tang 2012 \{published data only\}}

Tang J. Study of Birth Control Use After Childbirth. http: //clinicaltrials.gov/ct2/show/NCT01443533 (accessed 27 Jun 2012). [: NCT01443533]

\section{Additional references}

\section{Balshem 2011}

Balshem $H$, Helfand $M$, Schünemann HJ, Oxman AD, Kunz R, Brozek J, et al.GRADE guidelines: 3. Rating the quality of evidence. Journal of Clinical Epidemiology 2011; 64(4):401-6.

\section{Borda 2010}

Borda MR, Winfrey W, McKaig C. Return to sexual activity and modern family planning use in the extended postpartum period: an analysis of findings from seventeen countries. African Journal of Reproductive Health. 2011/ 08/05 2010; Vol. 14, issue 4:72-9.

\section{Borrelli 2005}

Borrelli B, Sepinwall D, Ernst D, Bellg AJ, Czajkowski $\mathrm{S}$, Breger R, et al.A new tool to assess treatment fidelity and evaluation of treatment fidelity across 10 years of health behavior research. Journal of Consulting and Clinical Psychology 2005;73:852-60.

\section{CONSORT 2009}

CONSORT group. CONSORT: Transparent reporting of trials. http://www.consort-statement.org/ (accessed 15 Jul 2009).

Engin-Üstün 2007

Engin-Üstün Y, Üstün Y, Cetin F, Meydanh MM, Kafkash A, Sezgin B. Effect of postpartum counseling on postpartum contraceptive use. Archives of Gynecology and Obstetrics 2007;275:429-32.

\section{Fagan 2009}

Fagan EB, Rodman E, Sorensen EA, Landis S, Colvin GF. A survey of mothers' comfort discussing contraception with infant providers at well-child visits. Southern Medical Journal. 2009/02/11 2009; Vol. 102, issue 3:260-4.

\section{FHI 2009}

Family Health International. Quick Reference Guide to Family Planning Research. Available from http:// www.fhi.org/en/RH/Programs/RtoP/underusedres.htm 2009:48-51.

\section{Glasier 1996}

Glasier AF, Logan J, McGlew TJ. Who gives advice about postpartum contraception?. Contraception 1996;53: 217-20.

\section{Glazer 2011}

Glazer AB, Wolf A, Gorby N. Postpartum contraception: needs vs. reality. Contraception. 2011/02/12 2011; Vol. 83, issue 3:238-41.

\section{Guyatt 2011}

Guyatt G, Oxman AD, Akl EA, Kunz R, Vist G, Brozek J, et al.GRADE guidelines: 1 . Introduction-GRADE evidence profiles and summary of findings tables. Journal of Clinical Epidemiology 2011;64(4):383-94.

\section{Higgins 2011}

Higgins JPT, Green S (editors). Cochrane Handbook for Systematic Reviews of Interventions 5.1.0 [updated March 2011]. The Cochrane Collaboration, 2011. Available from www.cochrane-handbook.org. John Wiley \& Sons, Ltd, (accessed 26 Mar 2012).

\section{Keith 1980}

Keith 1, Berger GS. Control of reproduction in the puerperal state.. In: Aladjem S, editor. Obstetrical practice. St. Louis: CV Mosby Company, 1980:Chapter 16.

\section{Koenig 1992}

Koenig MA, Rob U, Khan MA, Chakraborty J, Fauveau V. Contraceptive use in Matlab, Bangladesh in 1990: levels, trends, and explanations. Studies in Family Planning 1992; 23(6 Pt 1):352-64.

\section{Lopez 2011}

Lopez LM, Tolley EE, Grimes DA, Chen-Mok M. Theorybased interventions for contraception. Cochrane Database of Systematic Reviews 2011, Issue 3. [DOI: 10.1002/ 14651858.CD007249]

\section{Ozvaris 1997}

Ozvaris SB, Akin A, Yildiran M. Acceptability of postpartum contraception in Turkey. Advances in Contraceptive Delivery Systems 1997;13:63-71.

\section{Ross 2001}

Ross JA Winfrey WL. Contraceptive use, intention to use and unmet need during the extended postpartum period. International Family Planning Perspectives 2001;27:20-7.

Semeraro 1996

Semeraro P. Postpartum family planning services: Challenges for the future.. In: Murray, SF editor(s). In: Midwives and safer motherhood. London: Mosby, 1996: Chapter 6. 
Shaw 2007

Shaw E, Kaczorowski J. Postpartum care - what's new?

. Current Opinion in Obstetrics and Gynecology 2007;19:

561-7.

Thurman 2007

Thurman AR, Hammond N, Brown HE, Roddy ME.

Preventing repeat teen pregnancy: postpartum depot medroxyprogesterone acetate, oral contraceptive pills, or the patch?. Journal of Pediatric and Adolescent Gynecology 2007; 20:61-5.

USAID 2012

United States Agency for International Development. Postpartum Family Planning. http://archive.k4health.org/ toolkits/ppfp (accessed 30 May 2012).

Wilson 2011

Wilson EK, Samandari G, Koo HP, Tucker C. Adolescent mothers' postpartum contraceptive use: a qualitative study.
Perspectives on Sexual and Reproductive Health. 2011/12/

14 2011; Vol. 43, issue 4:230-7.

\section{Winikoff 1991}

Winikoff B, Mensch B. Rethinking postpartum family planning. Studies in Family Planning 1991;22:294-307.

\section{Zatuchni 1970}

Zatuchni GI. Introduction.. In: Zatuchni GI editor(s).

Postpartum family planning: A report on the international program. New York: McGraw Hill, 1970.

\section{References to other published versions of this review}

\section{Hay-Smith 1994}

Hay-Smith J. Education on contraceptive use by postpartum mothers [revised 27 January 1994]. Cochrane Collaboration; Pregnancy and Childbirth Module. Oxford: Update software, 1994; Vol. 2.

* Indicates the major publication for the study 


\section{CHARACTERISTICS OF STUDIES}

\section{Characteristics of included studies [ordered by study ID]}

\section{Barnet 2009}

\begin{tabular}{|c|c|}
\hline Methods & RCT conducted in Baltimore, MD (USA) \\
\hline Participants & $\begin{array}{l}237 \text { pregnant adolescents from } 5 \text { prenatal care clinics serving low-income, mainly African } \\
\text { American communities. Inclusion criteria: } 12 \text { to } 18 \text { years old, pregnancy } 24 \text { or more } \\
\text { weeks' gestation. } \\
\text { Exclusion criteria: pregnancy did not result in a live birth and withdrawn if the infant } \\
\text { died in the neonatal period, since parenting was an intervention focus }\end{array}$ \\
\hline Interventions & $\begin{array}{l}\text { Computer-assisted motivational intervention (CAMI) on quarterly basis; motivational } \\
\text { interviewing on contraception by CAMI counselors; parenting curriculum from Black } \\
\text { 2006, which included contraception. } \\
\text { 1) CAMI+: multi-component home-visiting intervention (parent training and case man- } \\
\text { agement); } \\
\text { 2) CAMI-only: single component, home-based intervention } \\
\text { 3) Usual care } \\
\text { Duration: } 6 \text { weeks to } 24 \text { months postpartum with maximum of } 9 \text { quarterly sessions }\end{array}$ \\
\hline Outcomes & $\begin{array}{l}\text { Repeat birth by } 24 \text { months postpartum (assessed via Vital Statistics); abortion since index } \\
\text { child's birth } \\
\text { Additional data provided by researcher: losses by arm to help interpret abortion infor- } \\
\text { mation obtained at } 24 \text {-month interview }\end{array}$ \\
\hline Notes & $\begin{array}{l}\text { If participant became pregnant, CAMI was stopped because questions on contraception } \\
\text { were no longer relevant and the program did not allow skipping } \\
\text { Sample size calculation (and outcome of focus): not specified (ns) } \\
\text { Secondary article (Barnet 2010) examined cost-effectiveness. }\end{array}$ \\
\hline
\end{tabular}

\section{Risk of bias}

\begin{tabular}{|c|c|c|}
\hline Bias & Authors' judgement & Support for judgement \\
\hline $\begin{array}{l}\text { Random sequence generation (selection } \\
\text { bias) }\end{array}$ & Low risk & $\begin{array}{l}\text { Randomly assigned, 'computer-generated } \\
\text { permuted blocks'. In communications, re- } \\
\text { searcher stated the ratio was } 3: 3: 2 \text {; with } 6 \\
\text { used for intervention groups and } 4 \text { for con- } \\
\text { trol. Block size of } 16 \text { would account for the } \\
\text { ratio rather than block size of } 6 \text { that was } \\
\text { reported in paper }\end{array}$ \\
\hline Allocation concealment (selection bias) & Unclear risk & No information \\
\hline $\begin{array}{l}\text { Blinding (performance bias and detection } \\
\text { bias) } \\
\text { All outcomes }\end{array}$ & Unclear risk & No information \\
\hline
\end{tabular}

Education for contraceptive use by women after childbirth (Review) 
Barnet 2009 (Continued)

\begin{tabular}{|c|c|c|}
\hline $\begin{array}{l}\text { Incomplete outcome data (attrition bias) } \\
\text { All outcomes }\end{array}$ & Low risk & $\begin{array}{l}\text { Researcher provided losses by study arm } \\
\text { (counts and \%) at } 24 \text { month-interview } \\
\text { Losses to follow-up: overall loss } 19 \% \text {; by } \\
\text { group, } 17 \% \text { CAMI+, 16\% CAMI-only, } \\
24 \% \text { Usual care } \\
\text { Exclusions after randomization: } 1 \text { partici- } \\
\text { pant with stillborn infant and } 1 \text { whose } 2- \\
\text { month-old infant died }\end{array}$ \\
\hline
\end{tabular}

Bashour 2008

Methods

Participants

Interventions

Outcomes

Notes

RCT with 3 arms; conducted at Maternity Teaching Hospital in Damascus, Syria

903 women who recently gave birth. Inclusion criteria: delivered healthy newborn, lived within $30 \mathrm{~km}$ of hospital, and available for 6 months. Exclusion criteria: delivered prematurely; baby weighed $<2500 \mathrm{~g}$ or had congenital anomaly

Home visits to educate and support women who had recently given birth. Registered midwives had 5 days of special training for the home visits. Breastfeeding was addressed in visits 2 and 3; family planning in visit 4 .

Group A: 4 home visits on days 1, 3, 7, 30 following delivery

Group B: visit on day 3, similar to visit to Group A (included breastfeeding but not family planning)

Group C: standard of care in Syria - no visit after discharge

Primary outcomes included self-reported pregnancy and contraceptive use and type (pills, IUD, condoms, others); assessed at 4 months postpartum

Power analysis based on postpartum morbidity, i.e., hemorrhoids: ability to detect decrease from $15 \%$ in control to $7 \%$ in treatment group

\section{Risk of bias}

\begin{tabular}{|c|c|c|}
\hline Bias & Authors' judgement & Support for judgement \\
\hline $\begin{array}{l}\text { Random sequence generation (selection } \\
\text { bias) }\end{array}$ & Low risk & $\begin{array}{l}\text { Communication with researcher indicated } \\
\text { block size was } 21 \text { with } 7 \text { assigned to each } \\
\text { study arm } \\
\text { Report had indicated randomization in } \\
\text { 'blocks of } 7 \text {...caseload of } 21 \text { eligible deliv- } \\
\text { eries per day was assumed' }\end{array}$ \\
\hline Allocation concealment (selection bias) & Low risk & $\begin{array}{l}\text { Numbered opaque and sealed envelopes; } \\
\text { process supervised by midwives not other- } \\
\text { wise involved in the study }\end{array}$ \\
\hline
\end{tabular}

Education for contraceptive use by women after childbirth (Review)

Copyright $\odot 2012$ The Cochrane Collaboration. Published by John Wiley \& Sons, Ltd. 
Bashour 2008 (Continued)

\begin{tabular}{|c|c|c|}
\hline $\begin{array}{l}\text { Blinding (performance bias and detection } \\
\text { bias) } \\
\text { All outcomes }\end{array}$ & Low risk & $\begin{array}{l}\text { Midwives who did home visits were not } \\
\text { blinded. Outcome assessors were blinded } \\
\text { to assignment; they could tell the assign- } \\
\text { ment from interviews but not fully aware } \\
\text { of study objectives }\end{array}$ \\
\hline $\begin{array}{l}\text { Incomplete outcome data (attrition bias) } \\
\text { All outcomes }\end{array}$ & Low risk & $\begin{array}{l}903 \text { women randomized; } 876 \text { completed } \\
\text { study. Losses of } 3 \% \text { were due to refusals }(\mathrm{N}= \\
\text { 9) or bad addresses }(\mathrm{N}=18) \text {. 'Bad addresses' } \\
\text { by group: } 5 \% \text { Group A }(\mathrm{N}=15) ; 1 \% \text { Group } \\
\text { B }(\mathrm{N}=3) \text {; none from Group C }\end{array}$ \\
\hline
\end{tabular}

Black 2006

\begin{tabular}{ll}
\hline Methods & RCT conducted in 3 urban hospitals in Baltimore, MD (USA) \\
\hline Participants & 181 female adolescents. Inclusion criteria: low income $(<185 \%$ poverty level $),<18$ years \\
& old, first-time delivery, black race, no indication of cocaine or heroin use in chart, no \\
& chronic illness that would interfere with parenting or adolescent development; infant \\
& was term $(>=37$ weeks $)$ and $>2500$ g; infant had no congenital problem, chronic illness, \\
& or disability
\end{tabular}

Interventions

Study focus: delaying second births - parenting, contraception

1) Home-based curriculum for adolescent mothers, maximum of 19 lessons; participants were seen twice per month until infant's first birthday. Intervention included information about access to birth control, and condoms were provided at each visit. After the first 2 visits, facilitators could vary the order of sessions, as well as combine or repeat them.

2) Usual care

Duration: maximum of 19 visits for experimental group at 2 per month $(40 \%$ had $>=8$ visits); evaluation visits occurred at 6,13 , and 24 months for both groups

Outcomes

Primary: Second birth by 24 months (assessed in home); contraceptive use was presented by second birth rather than by randomized group

Notes Sample size calculation (and outcome of focus): not specified

We were unsuccessful in obtaining data on contraceptive use by study arm

Risk of bias

\begin{tabular}{|c|c|c|}
\hline Bias & Authors' judgement & Support for judgement \\
\hline $\begin{array}{l}\text { Random sequence generation (selection } \\
\text { bias) }\end{array}$ & Unclear risk & $\begin{array}{l}\text { "Randomization procedure" stratified on } \\
\text { maternal age and child's gender }\end{array}$ \\
\hline Allocation concealment (selection bias) & Unclear risk & No information \\
\hline
\end{tabular}

Education for contraceptive use by women after childbirth (Review) 
Black 2006 (Continued)

\begin{tabular}{|c|c|c|}
\hline $\begin{array}{l}\text { Blinding (performance bias and detection } \\
\text { bias) } \\
\text { All outcomes }\end{array}$ & Unclear risk & No information \\
\hline $\begin{array}{l}\text { Incomplete outcome data (attrition bias) } \\
\text { All outcomes }\end{array}$ & Unclear risk & $\begin{array}{l}\text { Losses to follow-up: overall, } 18 \% \text {; by } \\
\text { group, intervention } 20 \%(17 / 87) \text {; control } \\
16 \%(15 / 94) \\
\text { Exclusions after randomization: excluded } \\
\text { from analysis } 32 \text { mothers who did not have } \\
\text { a } 24 \text {-month evaluation ( } 17 \text { treatment and } \\
15 \text { control), purportedly because the intent } \\
\text { was to assess second births. These young } \\
\text { women may have had } 6 \text {-month or } 13- \\
\text { month evaluations }\end{array}$ \\
\hline
\end{tabular}

Bolam 1998

Methods

Participants

Interventions

Outcomes

Notes
RCT, single site, conducted in main public maternity hospital in Kathmandu, Nepal from Nov 1994 to May 1996

540 women. Inclusion criteria: all pregnant women admitted to the hospital for delivery who resided in two communities

Experimental: One-to-one 20-minute health education session, interactive and supportive covering infant feeding, treatment of diarrhea, management of acute respiratory infection in infants, immunization, and contraception. The intervention was provided before discharge from hospital (with some emphasis on exclusive breastfeeding) with a second education session in the home 3 months post-delivery (with some emphasis on family planning).

Group A: Health education immediately after birth and at 3 months

Group B: Health education immediately after birth

Group C: Health education at 3 months

Group D: No health education

Primary: Duration of exclusive breast feeding and uptake of postnatal family planning (reported as one dichotomous item)

The intervention was designed to cover a range of important issues for maternal and infant health in Nepal.

Sample size was estimated for a range of outcomes; for family planning, sample size was based on $20 \%$ uptake in control and $33 \%$ in experimental group

\section{Risk of bias}

Authors' judgement
Support for judgement 
Bolam 1998 (Continued)

\begin{tabular}{|c|c|c|}
\hline $\begin{array}{l}\text { Random sequence generation (selection } \\
\text { bias) }\end{array}$ & Low risk & $\begin{array}{l}\text { Individual women were randomly allocated } \\
\text { either when in labor or shortly after deliv- } \\
\text { ery. Restricted randomization in blocks of } \\
20\end{array}$ \\
\hline Allocation concealment (selection bias) & Low risk & $\begin{array}{l}\text { Details in sealed envelopes for consecu- } \\
\text { tively recruited mothers }\end{array}$ \\
\hline $\begin{array}{l}\text { Blinding (performance bias and detection } \\
\text { bias) } \\
\text { All outcomes }\end{array}$ & Low risk & $\begin{array}{l}\text { Patients and health educators were not } \\
\text { blinded; outcome assessors were blind to } \\
\text { the group of assignment }\end{array}$ \\
\hline $\begin{array}{l}\text { Incomplete outcome data (attrition bias) } \\
\text { All outcomes }\end{array}$ & Low risk & $\begin{array}{l}\text { Loss to follow-up: } 25 \% \text { at } 3 \text { months and } \\
27 \% \text { at } 6 \text { months. Main reason was mother } \\
\text { moving back to parental home (cultural tra- } \\
\text { dition). } \\
\text { Exclusions (withdrawn from study): } 10 \text { in- } \\
\text { fant deaths spread across all study arms and } \\
2 \text { stillbirths }\end{array}$ \\
\hline
\end{tabular}

Gilliam 2004

Methods

RCT conducted at Northwestern Memorial Hospital, Chicago, IL (USA) from 1998 to 1999

Participants

33 African American low-income females attending Prentice Ambulatory Care. Participants were enrolled during prenatal care and randomized after delivery. This residentrun clinic serves low-income women receiving public assistance. Inclusion criteria: 25 years or younger; with unplanned pregnancy; intending to use OCs postpartum. Exclusion criterion: history of consistent or successful oral contraceptive (OC) use prior to pregnancy

Interventions

Postpartum, multi-component intervention consisting of counseling, a videotape about OCs, and written material versus resident-physician counseling (usual care)

Intervention was one-time, post-delivery.

Follow-up: one year.

Outcomes

Continuation rate at one year; switch to other contraceptives at one year; pregnancy rate at one year (most by self-report)

Adherence assessed through collection of pill packs and self-reports. Multiple questions asked to assess continuation

Notes

Knowledge of OCs mentioned, but data reported elsewhere. 43 women were enrolled but only 33 were randomized. Reasons for enrollment without randomization included participants changing their mind about using OCs, delivering at an outside hospital, and failure of the study team to randomize the participant prior to leaving the hospital due to miscommunication with nursing staff or leaving after a 24-hour rather than 48hour stay

Education for contraceptive use by women after childbirth (Review)

Copyright $\odot 2012$ The Cochrane Collaboration. Published by John Wiley \& Sons, Ltd. 
Gilliam 2004 (Continued)

\section{Risk of bias}

\begin{tabular}{|c|c|c|}
\hline Bias & Authors' judgement & Support for judgement \\
\hline $\begin{array}{l}\text { Random sequence generation (selection } \\
\text { bias) }\end{array}$ & Low risk & $\begin{array}{l}\text { Computer-generated random numbers ta- } \\
\text { ble; randomized following delivery }\end{array}$ \\
\hline Allocation concealment (selection bias) & Low risk & $\begin{array}{l}\text { Study packets were in envelopes that "con- } \\
\text { cealed the contents" }\end{array}$ \\
\hline $\begin{array}{l}\text { Blinding (performance bias and detection } \\
\text { bias) } \\
\text { All outcomes }\end{array}$ & Unclear risk & $\begin{array}{l}\text { Research team members were reportedly } \\
\text { blind to group participation; details not } \\
\text { provided }\end{array}$ \\
\hline $\begin{array}{l}\text { Incomplete outcome data (attrition bias) } \\
\text { All outcomes }\end{array}$ & Low risk & $\begin{array}{l}\text { Losses by } 1 \text { year: } 17 / 33=52 \% \text { dropped } \\
\text { out. Pregnancy data obtained on } 9 \text { of the } \\
\text { women that dropped out via records or } \\
\text { contacting participant, leaving data loss for } \\
8 / 33=24 \%\end{array}$ \\
\hline
\end{tabular}

Katz 2011

\begin{tabular}{ll}
\hline Methods & RCT conducted in Washington, DC (USA) and adjoining metropolitan area \\
\hline Participants & $\begin{array}{l}249 \text { pregnant or newly parenting teens recruited from prenatal clinics and local high } \\
\text { schools } \\
\text { Inclusion criteria: African American or Latina primiparous pregnant teens, aged } 15 \text { to } \\
18 \text { years as well as 19-year-olds who had not graduated from high school }\end{array}$ \\
\hline
\end{tabular}

Interventions

1) Intervention group $(\mathrm{N}=125)$ : curriculum goal was to improve reproductive health planning and motivate teens to delay further childbearing; focused on knowledge of health risks and positive teen attitudes. Other issues included sexual partner communication and negotiation, resisting peer pressure for risk behaviors, and connectedness with family, health care provider, school and work; minimal content on parenting Process: Teens received cell phones for 18 months of counseling sessions, and quarterly group sessions. Counselors met with each teen face-to-face, provided cell phones, and scheduled weekly cell phone counseling calls for first 6 months. Each teen was assigned one counselor for duration of study. Biweekly phone sessions were scheduled during subsequent 12 months for maximum of 42 phone counseling sessions over 18-month postpartum interval. Two-hour dinner group sessions, at one of the hospitals serving pregnant and parenting teens, were held quarterly over the two-year course of the study 2) Usual care $(\mathrm{N}=124)$ : health and education services generally provided through schools or healthcare facilities

Duration: 24 months

Outcomes

Time to subsequent conception. Pregnancy status assessed via telephone at 3, 9, 15 and 21 months; confirmed by urine pregnancy test at $6,12,18$ and 24 months 


\section{Katz 2011 (Continued)}

\begin{tabular}{|c|c|c|}
\hline Notes & \multicolumn{2}{|c|}{ Analysis according to treatment assignment. } \\
\hline \multicolumn{3}{|l|}{ Risk of bias } \\
\hline Bias & Authors' judgement & Support for judgement \\
\hline $\begin{array}{l}\text { Random sequence generation (selection } \\
\text { bias) }\end{array}$ & Low risk & $\begin{array}{l}\text { Random numbers table programmed } \\
\text { within web-based data management system } \\
\text { Stratified by age } 15 \text { to } 17 \text { or }>=18 \text { years } \\
\text { and by hospital of delivery }\end{array}$ \\
\hline Allocation concealment (selection bias) & Unclear risk & No information \\
\hline $\begin{array}{l}\text { Blinding (performance bias and detection } \\
\text { bias) } \\
\text { All outcomes }\end{array}$ & Unclear risk & No information \\
\hline $\begin{array}{l}\text { Incomplete outcome data (attrition bias) } \\
\text { All outcomes }\end{array}$ & Low risk & $\begin{array}{l}\text { Losses: Intervention } \mathrm{N}=5(4 \%) \text { and control } \\
\mathrm{N}=7(5.6 \%) \text { (dropped out }<21 \text { months } \\
\text { postpartum or }>3 \text { months before study } \\
\text { close) }\end{array}$ \\
\hline
\end{tabular}

O’Sullivan 1992

\begin{tabular}{l|l}
\hline Methods & RCT conducted in large urban teaching hospital in eastern USA \\
\hline Participants & $\begin{array}{l}243 \text { postpartum teenagers. Inclusion criteria: <= } 17 \text { years old, delivered a healthy baby } \\
\text { at the specified hospital, no previous children (though previous pregnancy acceptable) } \\
\text {. Exclusion criterion: planned to place child for adoption. All participants were single, } \\
\text { African American, and received Medicaid }\end{array}$ \\
\hline Interventions & $\begin{array}{l}\text { Special care versus routine well-baby care. } \\
\text { Special care differed from routine care in staffing and services: clinic was directed by } \\
\text { nurse practitioner, staffed by pediatrician, another nurse practitioner, and social worker; } \\
\text { goals included preventing repeat pregnancy, mother's return to school, up-to-date im- } \\
\text { munizations for infant, and less use of emergency care for infant; used reminder phone } \\
\text { calls and letters for appointments } \\
\text { Routine care included } 8 \text { appointments from } 2 \text { weeks postpartum to } 18 \text { months } \\
\text { Duration for both programs was } 18 \text { months. }\end{array}$ \\
\hline Outcomes & $\begin{array}{l}\text { Repeat pregnancy (self-report) and return to school by interview; attendance at clinic, } \\
\text { full immunization, and emergency room visit by chart review }\end{array}$ \\
\hline Notes & No apparent sample size estimation \\
\hline
\end{tabular}

\section{Risk of bias}


O’Sullivan 1992 (Continued)

\begin{tabular}{|c|c|c|}
\hline Bias & Authors' judgement & Support for judgement \\
\hline $\begin{array}{l}\text { Random sequence generation (selection } \\
\text { bias) }\end{array}$ & Unclear risk & No information \\
\hline Allocation concealment (selection bias) & Unclear risk & No information \\
\hline $\begin{array}{l}\text { Blinding (performance bias and detection } \\
\text { bias) } \\
\text { All outcomes }\end{array}$ & Unclear risk & No information \\
\hline $\begin{array}{l}\text { Incomplete outcome data (attrition bias) } \\
\text { All outcomes }\end{array}$ & Low risk & $\begin{array}{l}\text { Programs had high dropout rates, but } 91 \% \\
\text { overall were located for } 18 \text {-month inter- } \\
\text { view. Program dropouts by } 6 \text { months were } \\
37 \% \text { experimental and } 63 \% \text { routine care; } \\
\text { by } 18 \text { months, dropouts were } 60 \% \text { experi- } \\
\text { mental and } 82 \% \text { routine care }\end{array}$ \\
\hline
\end{tabular}

Proctor 2006

Methods

Participants

Interventions

Outcomes

Notes

Risk of bias
RCT conducted in Carolinas Medical Center; Charlotte, NC (USA)

329 women. Inclusion criteria: delivered live infant at $>34$ weeks gestation, speak English or Spanish, willing to be contacted at 3 and 6 months postpartum. Exclusion criteria: delivered premature infant, had fetal death, wanted sterilization, were illiterate, had no prenatal care, or had care outside the Center's prenatal system

Contraceptive counseling on postpartum day 1 by

a) 20-minute video presentation ('Hope Is Not a Method' in English or Spanish),

b) educational literature with same content as video, or

c) physician-patient counseling session (similar content to other 2 methods but not scripted)

Patient satisfaction with method of 'counseling' (questionnaire after counseling session) . Satisfaction was assessed with only 1 dichotomous item.

Data for contraceptive choice (on postpartum day 2) were presented in a graph and could not be used in analysis here. Unable to obtain data from researcher

Power analysis based on detecting $10 \%$ difference between groups in satisfaction, but estimate of baseline satisfaction not provided

\section{Bias}

Authors' judgement

Random sequence generation (selection Low risk bias)

\section{Support for judgement}

Block randomization with "computer-generated numbers." Stratified by English- or Spanish-speaking status 


\section{Proctor 2006 (Continued)}

\begin{tabular}{l|l|l}
\hline Allocation concealment (selection bias) & Low risk & Sealed, opaque envelopes \\
\hline $\begin{array}{l}\text { Blinding (performance bias and detection } \\
\text { bias) } \\
\text { All outcomes }\end{array}$ & Unclear risk & None apparent \\
\hline $\begin{array}{l}\text { Incomplete outcome data (attrition bias) } \\
\text { All outcomes }\end{array}$ & Low risk & $\begin{array}{l}\text { Excluded } 10 \text { cases after randomization due } \\
\text { to incomplete questionnaire (4), discharge } \\
\text { prior to counseling (3), patient withdrawal } \\
\text { (2), or illiteracy (1) }\end{array}$ \\
\hline
\end{tabular}

Quinlivan 2003

\begin{tabular}{|c|c|c|}
\hline Methods & \multicolumn{2}{|c|}{$\begin{array}{l}\text { RCT conducted in Australia clinic from Jul } 1998 \text { to Dec 2000. Enrolled prenatally; } \\
\text { randomized immediately after delivery }\end{array}$} \\
\hline Participants & \multicolumn{2}{|c|}{$\begin{array}{l}139 \text { teenagers, first-time mothers. Inclusion criteria: }<18 \text { years old, speak English, intend } \\
\text { to continue with pregnancy and to keep infant. } \\
\text { Exclusion criteria: living }>150 \mathrm{~km} \text { from hospital or known fetal abnormality }\end{array}$} \\
\hline Interventions & \multicolumn{2}{|c|}{$\begin{array}{l}\text { Both groups had routine postnatal support, counseling, and information from the hos- } \\
\text { pital, including access to routine home-visiting. Experimental group also had structured } \\
\text { home visits ( } 1 \text { to } 4 \text { hours each) from nurse midwives at week } 1 \text { and } 2 \text { and at months } 1 \text {, } \\
2,4 \text {, and } 6\end{array}$} \\
\hline Outcomes & \multicolumn{2}{|c|}{$\begin{array}{l}\text { Primary included knowledge regarding contraception and breastfeeding; insufficient data } \\
\text { available for analysis here } \\
\text { Secondary included effective use of contraception (defined as following manufacturer's } \\
\text { guidelines and without use of emergency contraception) }\end{array}$} \\
\hline Notes & \multicolumn{2}{|c|}{$\begin{array}{l}\text { Sample size estimate based on ability to detect increase in knowledge score. } \\
\text { Due to the age of the study (conducted } 1998 \text { to 2000), we did not request additional } \\
\text { data from the researcher }\end{array}$} \\
\hline \multicolumn{3}{|l|}{ Risk of bias } \\
\hline Bias & Authors' judgement & Support for judgement \\
\hline $\begin{array}{l}\text { Random sequence generation (selection } \\
\text { bias) }\end{array}$ & Low risk & "Generated by computer" \\
\hline Allocation concealment (selection bias) & Low risk & Numbered, sealed, opaque envelopes \\
\hline $\begin{array}{l}\text { Blinding (performance bias and detection } \\
\text { bias) } \\
\text { All outcomes }\end{array}$ & Unclear risk & no information \\
\hline
\end{tabular}


Quinlivan 2003 (Continued)

Incomplete outcome data (attrition bias) Low risk All outcomes
3 withdrawn before randomization due to late fetal loss.

136 randomized; 124 completed trial. 11 withdrawals due to adverse neonatal outcomes (identified in flow chart) and 1 consent withdrawn

Saeed 2008

Methods

Participants

Interventions

Notes
RCT conducted in hospital in Islamabad, Pakistan from Feb 2006 to Sep 2007

Women admitted to labor ward from Feb 2006 to Sep 2007 after delivery (N=648), regardless of pregnancy duration, delivery mode or fetal outcome

Intervention: 20-minute informal counseling regarding contraception in presence of husband or other close relative. Didactic approach used with opportunity to ask questions. One-page pamphlet provided on contraceptive methods. Providers had 40-minute training on counseling leaflet and interview methods.

Control: no counseling or pamphlet provided.

Follow-up at 8 to 12 weeks postpartum

Contraceptive use postpartum (any being used or planned; method chosen)

We examined modern contraceptive use, i.e., we excluded coitus interruptus

No information on sample size estimation

\section{Risk of bias}

\begin{tabular}{l|ll}
\hline Bias & Authors' judgement & Support for judgement \\
\hline $\begin{array}{l}\text { Random sequence generation (selection } \\
\text { bias) }\end{array}$ & Low risk & $\begin{array}{l}\text { Randomized into 2 groups by "block of } 4 \\
\text { randomization charts" }\end{array}$ \\
\hline $\begin{array}{l}\text { Allocation concealment (selection bias) } \\
\text { Blinding (performance bias and detection } \\
\text { bias) } \\
\text { All outcomes }\end{array}$ & Low risk & no information \\
\hline $\begin{array}{l}\text { Incomplete outcome data (attrition bias) } \\
\text { All outcomes }\end{array}$ & Low risk & Physician recording follow-up data was \\
\hline
\end{tabular}


Characteristics of excluded studies [ordered by study ID]

\begin{tabular}{ll}
\hline Study & Reason for exclusion \\
\hline Barnet 2007 & Intervention began in the third trimester of pregnancy. \\
\hline Christie 2011 & No mention of contraception. \\
\hline El-Kamary 2004 & $\begin{array}{l}\text { Family planning only had to be provided within 12-month period of the program for 90\% of clients. } \\
\text { Therefore, contraception education was not an integral part of the intervention }\end{array}$ \\
\hline Foreit 1993 & $\begin{array}{l}\text { Two maternity floors and their associated outpatient clinics were randomly selected and randomly assigned } \\
\text { to treatment and control groups. Women were assigned to a maternity floor based on availability. Analysis } \\
\text { could not be adjusted for the cluster assignment with only two units (floors) }\end{array}$ \\
\hline
\end{tabular}

Lee 2007 Assignment adapted from Sayegh 1976. Coin flip determined which rooms were assigned to program first. Even-numbered rooms were the experimental group and odd-numbered were the control group. Cluster assignment (by room) not addressed in the analysis

Lee $2011 \quad$ Assignment adapted from Sayegh 1976 and similar to that used in Lee 2007.

Odd-numbered wards were the experimental group and were divided in half (wards 1,3,5,7,11 and wards $13,15,17,19,21,23)$. Even numbered wards were the control group. Coin flip determined which half of the experimental group received the program first; midway through the study, the other half received the program. Rooms with double occupancy were assigned as a unit. Cluster assignment (by room) not addressed in the analysis

Nacar $2003 \quad$ Allocation likely to have been alternate. Questionnaire about eligibility criteria was administered to intervention and control groups on alternate days. The intervention was given immediately following the questionnaire.

\begin{tabular}{ll}
\hline Norr 2003 & No apparent education on contraception \\
\hline Olds 2002 & Enrolled prenatally; no clear starting point for home visits after delivery - could have been a month or longer \\
\hline Omu 1989 & Intervention began during pregnancy. \\
\hline Ranjjo-Arvidson 1998 & No apparent education on contraception (no standard health education) \\
\hline Sayegh 1976 & $\begin{array}{l}\text { Alternate rooms allocated to educational program using a coin toss to determine starting point. Patients were } \\
\text { allocated to } 1 \text { of } 10 \text { rooms (2 beds each) based on availability. Cluster assignment (by room) not addressed } \\
\text { in the analysis }\end{array}$ \\
\hline Smith 2002 & $\begin{array}{l}\text { Experimental group did not receive any education postpartum (only prenatally). Some of the controls } \\
\text { (standard local counseling) had some postpartum education }\end{array}$ \\
\hline
\end{tabular}

Education for contraceptive use by women after childbirth (Review)

Copyright $\odot 2012$ The Cochrane Collaboration. Published by John Wiley \& Sons, Ltd. 


\section{Dulli 2010}

Trial name or title Improving access to and uptake of postpartum family planning service through enhanced family planning (FP) in immunization services in Rwanda.

\begin{tabular}{ll} 
Methods & $\begin{array}{l}\text { Randomized trial; open label } \\
\text { Two-group, pretest and posttest design }\end{array}$ \\
\hline Participants & $\begin{array}{l}800 \text { women attending vaccination services for their infants, as well as vaccination and FP } \\
\text { providers } \\
\text { Inclusion criteria for clients: adult women, aged } 21 \text { years and older, or married women ages } 18 \text { to } 20 \text { who } \\
\text { have achieved legal majority status by emancipation due to marriage; bring their infants age } 6 \text { to } 12 \text { months } \\
\text { to immunization services at study sites } \\
\text { Inclusion criteria for providers: health care providers who provide immunization services to infants or family } \\
\text { planning services within selected facilities }\end{array}$ \\
\hline
\end{tabular}

Interventions $\quad$ 1) Family planning for postpartum women included:

- Group education sessions regarding pregnancy risk, benefits of FP, and family planning options during postpartum period.

- Materials that deliver messages about benefits of spacing pregnancies by at least 2 years, LAM (lactational amenorrhea), return to fecundity and pregnancy risk during postpartum period and contraceptive options for postpartum women.

- Use of screening tool to assess pregnancy risk for postpartum women coupled with brief counseling message and referral to FP services.

- Convenient offer of FP services to women attending vaccination services for their infants.

2) Control: Standard of care infant immunization services.

12-month intervention period

Outcomes Use of a modern contraceptive method among postpartum women

Starting date Feb 2010

Contact information Principal Investigator: Lisa S. Dulli, ldulli@fhi360.org; +254-71-479-1057

Notes $\quad$ ClinicalTrials.gov last updated 3 May 2010.

Communications with L Dulli (Apr 2012): recently completed data collection and currently analyzing data

\section{Sadler 2011}

\begin{tabular}{ll} 
Trial name or title & Minding the baby home visiting: program evaluation \\
\hline Methods & Randomized trial, single blind (outcomes assessor) at two sites in New Haven, CT (USA) \\
\hline Participants & $\begin{array}{l}150 \text { first-time mothers, age } 14 \text { to } 25 \text { years } \\
\text { Inclusion criteria: having a first child, speak English, and obtain primary care from community health center } \\
\text { Exclusion criteria: no psychosis or terminal illness }\end{array}$
\end{tabular}


Sadler 2011 (Continued)

\begin{tabular}{ll}
\hline Interventions & $\begin{array}{l}\text { Experimental: weekly home visits for one year, followed by bi-weekly home visits until child is 24 months of } \\
\text { age, provided to young at-risk families by team of nurse practitioner and social worker home visitors } \\
\text { No Intervention: routine primary care at community health center }\end{array}$ \\
\hline Outcomes & $\begin{array}{l}\text { Primary: maternal life course outcomes (delay rapid subsequent childbearing within } 24 \text { months of older child's } \\
\text { birth), as well as maternal reflective capacities, infant attachment, and child abuse or neglect } \\
\text { Secondary: dose of intervention, cost analysis for program, and description of reflective functioning in pregnant } \\
\text { adolescents }\end{array}$ \\
\hline Starting date & Sep 2009; estimated completion Aug 2014 \\
\hline Contact information & $\begin{array}{l}\text { Patricia Miller: 1-203-785-5589; patricia.miller@yale.edu } \\
\text { Andrea Miller: 1-203-785-5589; andrea.miller@yale.edu }\end{array}$ \\
\hline Notes & ClinicalTrials.gov last updated 20 Oct 2011 \\
\hline
\end{tabular}

Tang 2012

\begin{tabular}{l|l}
\hline Trial name or title & $\begin{array}{l}\text { Study of Birth Control Use After Childbirth } \\
\text { Official title: A Randomized Controlled Trial of a Brief Educational Script on Postpartum Contraceptive } \\
\text { Uptake }\end{array}$ \\
\hline Methods & $\begin{array}{l}\text { Randomized trial conducted at one hospital in Raleigh, North Carolina (USA). Double blind (investigator } \\
\text { and outcomes assessor) }\end{array}$ \\
\hline Participants & $\begin{array}{l}\text { 800 healthy postpartum women. } \\
\text { Inclusion criteria: } \\
\text { - Women who are admitted to the postpartum unit at WakeMed Hospital } \\
\text { - Delivery of a live infant }>24 \text { weeks gestational age } \\
\text { - Age } 14 \text { to } 45 \text { years } \\
\text { - Ability to speak either English or Spanish fluently } \\
\text { - Willing to be contacted by phone until at least } 8 \text { weeks after delivery } \\
\text { Exclusion criteria: } \\
\text { - History of a tubal ligation or hysterectomy } \\
\text { - Partner has already had a vasectomy } \\
\text { - History of fertility treatment to conceive this pregnancy } \\
\text { - Previous randomization into the study. }\end{array}$ \\
\hline
\end{tabular}

Interventions

1) Routine postpartum counseling plus one-minute script ("LARC script"), given to women during their postpartum admission. The script informs women about long-acting reversible contraceptive (LARC) methods, specifically the contraceptive implant and the intrauterine device

2) Routine postpartum counseling (no LARC script)

Outcomes

Primary: self-reported use of LARC method after six-week postpartum visit Secondary: Self-reported interest in use of a LARC method, self-reported use of any contraceptive method, self-reported reasons for not using the contraceptive method of choice (all after six-week postpartum visit) 
Tang 2012 (Continued)

Starting date May 2011; data collection completed May 2012. Data are currently being analyzed, according to PI

Contact information Jennifer Tang, Principal Investigator, University of North Carolina at Chapel Hill jennifer.h.tang@gmail.com

Notes

Correspondence with principle investigator indicated comparison group has routine postpartum counseling with no LARC script. ClinicalTrials.gov posting will be updated to reflect this 
DATA AND ANALYSES

Comparison 1. Oral contraceptive education program (one time) versus routine counseling

\begin{tabular}{lcccc} 
Outcome or subgroup title & $\begin{array}{c}\text { No. of } \\
\text { studies }\end{array}$ & $\begin{array}{c}\text { No. of } \\
\text { participants }\end{array}$ & Statistical method & Effect size \\
\hline $\begin{array}{l}1 \text { Continuation of oral } \\
\text { contraceptives at one year }\end{array}$ & 1 & 25 & Odds Ratio (M-H, Fixed, 95\% CI) & $0.67[0.11,3.99]$ \\
$\begin{array}{l}\text { Switched contraceptives by one } \\
\text { year }\end{array}$ & 1 & 25 & Odds Ratio (M-H, Fixed, 95\% CI) & $2.0[0.37,10.92]$ \\
3 Known pregnancy by one year & 1 & 25 & Odds Ratio (M-H, Fixed, 95\% CI) & $0.81[0.11,6.04]$ \\
\hline
\end{tabular}

Comparison 2. Contraceptive information (one time): physician counseling versus video versus pamphlet

\begin{tabular}{lcccc} 
Outcome or subgroup title & $\begin{array}{c}\text { No. of } \\
\text { studies }\end{array}$ & $\begin{array}{c}\text { No. of } \\
\text { participants }\end{array}$ & Statistical method & Effect size \\
\hline $\begin{array}{l}1 \text { Satisfied with 'counseling' } \\
\text { after the session: video versus } \\
\text { physician }\end{array}$ & 1 & 218 & Odds Ratio (M-H, Fixed, 95\% CI) & $0.27[0.07,0.98]$ \\
$\begin{array}{l}2 \text { Satisfied with 'counseling' after } \\
\text { the session: video versus written } \\
\text { information }\end{array}$ & 1 & 218 & Odds Ratio (M-H, Fixed, 95\% CI) & $0.75[0.29,1.92]$ \\
\hline
\end{tabular}

Comparison 3. Contraceptive counseling (one time) versus no counseling

\begin{tabular}{lccccc} 
Outcome or subgroup title & $\begin{array}{c}\text { No. of } \\
\text { studies }\end{array}$ & $\begin{array}{c}\text { No. of } \\
\text { participants }\end{array}$ & Statistical method & Effect size \\
\hline $\begin{array}{c}1 \text { Use of any contraceptive at } 8 \text { to } \\
12 \text { weeks postpartum }\end{array}$ & 1 & 600 & Odds Ratio (M-H, Fixed, 95\% CI) & $19.56[11.65,32.83]$ \\
$\begin{array}{c}\text { Choice of modern contraceptive } \\
\text { (using or plan to use) at } 8 \text { to } 12\end{array}$ & 1 & 600 & Odds Ratio (M-H, Fixed, 95\% CI) & $1038.09[64.15$, \\
$\quad$ weeks postpartum
\end{tabular}




\begin{tabular}{lcccc} 
Outcome or subgroup title & $\begin{array}{c}\text { No. of } \\
\text { studies }\end{array}$ & $\begin{array}{c}\text { No. of } \\
\text { participants }\end{array}$ & Statistical method & Effect size \\
\hline $\begin{array}{c}\text { Use of contraception at } 3 \\
\text { months: immediate session } \\
\text { versus no immediate session }\end{array}$ & 1 & 402 & Odds Ratio (M-H, Fixed, 95\% CI) & $1.50[0.88,2.54]$ \\
$\begin{array}{l}\text { Use of contraception at 6 } \\
\text { months: immediate session } \\
\text { versus no immediate session }\end{array}$ & 1 & 393 & Odds Ratio (M-H, Fixed, 95\% CI) & $1.62[1.06,2.50]$ \\
3 Use of contraception at 6 \\
months: immediate plus later \\
sessions versus immediate \\
session
\end{tabular}

Comparison 5. Special postpartum care (including contraception) versus routine services (multiple well-baby contacts)

\begin{tabular}{lcccc} 
Outcome or subgroup title & $\begin{array}{c}\text { No. of } \\
\text { studies }\end{array}$ & $\begin{array}{c}\text { No. of } \\
\text { participants }\end{array}$ & Statistical method & Effect size \\
\hline $\begin{array}{l}1 \text { Repeat pregnancy (self-report) } \\
\text { by } 18 \text { months }\end{array}$ & 1 & 221 & Odds Ratio (M-H, Fixed, 95\% CI) & $0.35[0.17,0.70]$ \\
\hline
\end{tabular}


Comparison 6. Home visiting: structured versus routine

\begin{tabular}{lcccc} 
Outcome or subgroup title & $\begin{array}{c}\text { No. of } \\
\text { studies }\end{array}$ & $\begin{array}{c}\text { No. of } \\
\text { participants }\end{array}$ & Statistical method & Effect size \\
\hline $\begin{array}{l}1 \text { Effective contraception use at } 6 \\
\text { months }\end{array}$ & 1 & 124 & Odds Ratio (M-H, Fixed, 95\% CI) & $3.24[1.35,7.79]$ \\
\hline
\end{tabular}

Comparison 7. Home-based mentoring (multiple visits) versus usual care

\begin{tabular}{lcccc} 
Outcome or subgroup title & $\begin{array}{c}\text { No. of } \\
\text { studies }\end{array}$ & $\begin{array}{c}\text { No. of } \\
\text { participants }\end{array}$ & Statistical method & Effect size \\
\hline 1 Second birth by 24 months & 1 & 149 & Odds Ratio (M-H, Fixed, 95\% CI) & $0.41[0.17,1.00]$ \\
\hline
\end{tabular}

Comparison 8. Computer-assisted motivational interviewing (CAMI) with parenting curriculum versus CAMIonly versus usual care

\begin{tabular}{|c|c|c|c|c|}
\hline Outcome or subgroup title & $\begin{array}{l}\text { No. of } \\
\text { studies }\end{array}$ & $\begin{array}{c}\text { No. of } \\
\text { participants }\end{array}$ & Statistical method & Effect size \\
\hline 1 Repeat birth by 24 months & 1 & & Odds Ratio (M-H, Fixed, 95\% CI) & Subtotals only \\
\hline $\begin{array}{l}\text { 1.1 CAMI + parenting } \\
\text { curriculum versus usual care }\end{array}$ & 1 & 148 & Odds Ratio (M-H, Fixed, 95\% CI) & $0.48[0.21,1.11]$ \\
\hline $\begin{array}{l}\text { 1.2 CAMI-only versus usual } \\
\text { care }\end{array}$ & 1 & 155 & Odds Ratio (M-H, Fixed, 95\% CI) & $0.63[0.29,1.37]$ \\
\hline
\end{tabular}

Comparison 9. Phone counseling versus usual services

\begin{tabular}{lccccc} 
Outcome or subgroup title & $\begin{array}{c}\text { No. of } \\
\text { studies }\end{array}$ & $\begin{array}{c}\text { No. of } \\
\text { participants }\end{array}$ & Statistical method & Effect size \\
\hline 1 Repeat pregnancy by 24 months & 1 & 249 & Odds Ratio (M-H, Fixed, 95\% CI) & $0.80[0.47,1.35]$ \\
\hline
\end{tabular}


Comparison 10. Home visiting: four visits versus one visit versus usual care

\begin{tabular}{lcccc} 
Outcome or subgroup title & $\begin{array}{c}\text { No. of } \\
\text { studies }\end{array}$ & $\begin{array}{c}\text { No. of } \\
\text { participants }\end{array}$ & Statistical method & Effect size \\
\hline $\begin{array}{l}\text { 1 Contraception use at 4 months: } \\
\quad \text { visits versus 1 visit }\end{array}$ & 1 & 565 & Odds Ratio (M-H, Fixed, 95\% CI) & $1.25[0.89,1.75]$ \\
$\begin{array}{l}\text { Contraception use at 4 months: } \\
1 \text { visit versus usual care }\end{array}$ & 1 & 580 & Odds Ratio (M-H, Fixed, 95\% CI) & $0.86[0.62,1.20]$ \\
$\begin{array}{l}3 \text { Pregnancy (self-reported) at } 4 \\
\text { months postpartum: 4 visits } \\
\text { versus 1 visit }\end{array}$ & 1 & 554 & Odds Ratio (M-H, Fixed, 95\% CI) & $1.49[0.33,6.74]$ \\
$\begin{array}{l}4 \text { Pregnancy (self-reported) at 4 } \\
\text { months postpartum: 1 visit } \\
\text { versus usual care }\end{array}$ & 1 & 585 & Odds Ratio (M-H, Fixed, 95\% CI) & $1.00[0.20,5.01]$ \\
\hline
\end{tabular}

Analysis I.I. Comparison I Oral contraceptive education program (one time) versus routine counseling, Outcome I Continuation of oral contraceptives at one year.

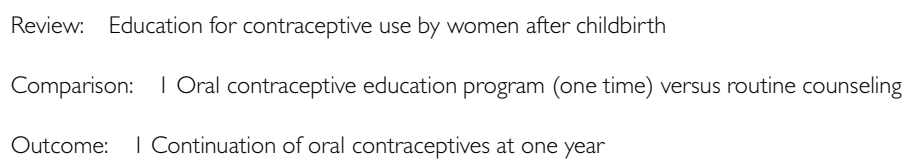

\begin{tabular}{|c|c|c|c|c|c|c|}
\hline \multirow[t]{2}{*}{ Study or subgroup } & Experimental & Control & & Odds Ratio & Weight & Odds Ratio \\
\hline & $\mathrm{n} / \mathrm{N}$ & $\mathrm{n} / \mathrm{N}$ & & M-H,Fixed,95\% Cl & & M-H,Fixed,95\% Cl \\
\hline Gilliam 2004 & $4 / 16$ & $3 / 9$ & & $\longrightarrow$ & $100.0 \%$ & $0.67[0.11,3.99]$ \\
\hline Total $(95 \% \mathrm{CI})$ & 16 & 9 & & & $100.0 \%$ & $0.67[0.11,3.99]$ \\
\hline \multicolumn{7}{|c|}{ Total events: 4 (Experimental), 3 (Control) } \\
\hline \multicolumn{7}{|c|}{ Heterogeneity: not applicable } \\
\hline \multicolumn{7}{|c|}{ Test for overall effect: $Z=0.44(P=0.66)$} \\
\hline \multicolumn{7}{|c|}{ Test for subgroup differences: Not applicable } \\
\hline
\end{tabular}


Analysis I.2. Comparison I Oral contraceptive education program (one time) versus routine counseling, Outcome 2 Switched contraceptives by one year.

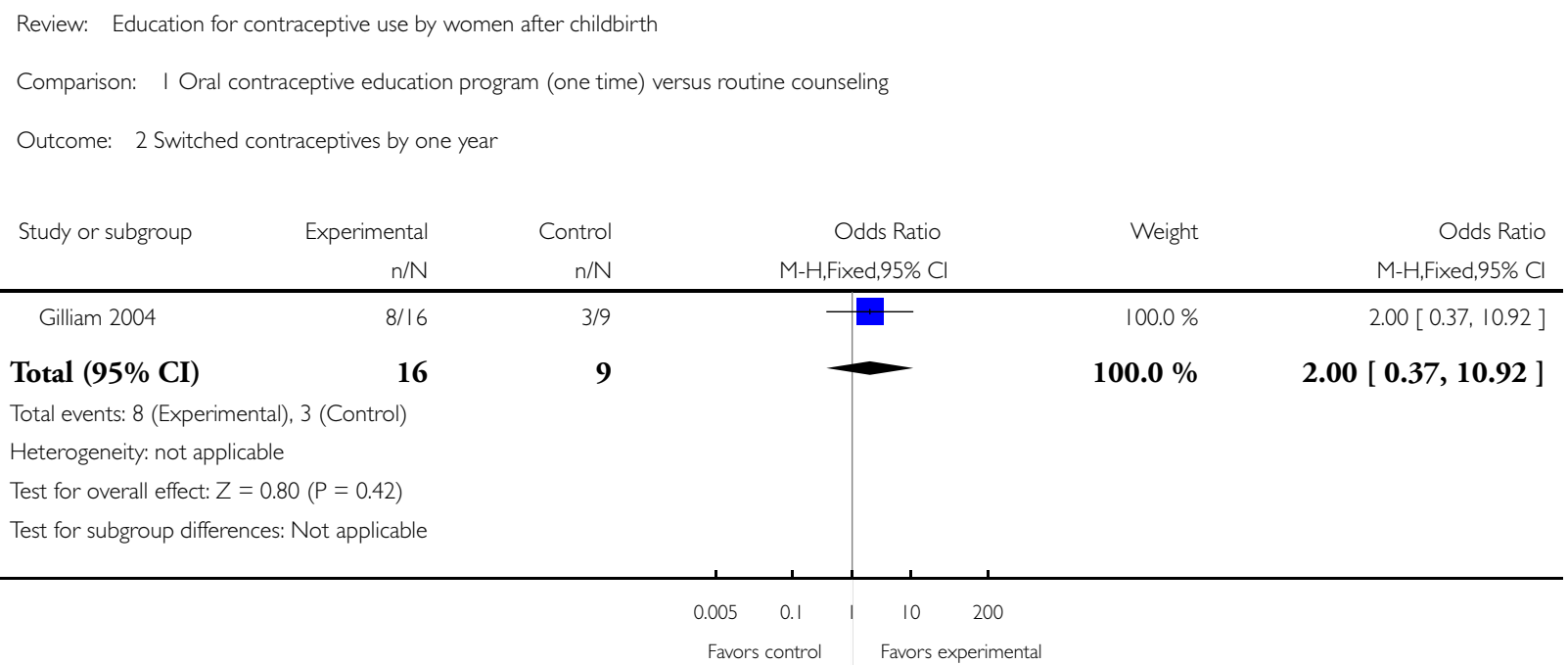

Analysis I.3. Comparison I Oral contraceptive education program (one time) versus routine counseling, Outcome 3 Known pregnancy by one year.

Review: Education for contraceptive use by women after childbirth

Comparison: I Oral contraceptive education program (one time) versus routine counseling

Outcome: 3 Known pregnancy by one year

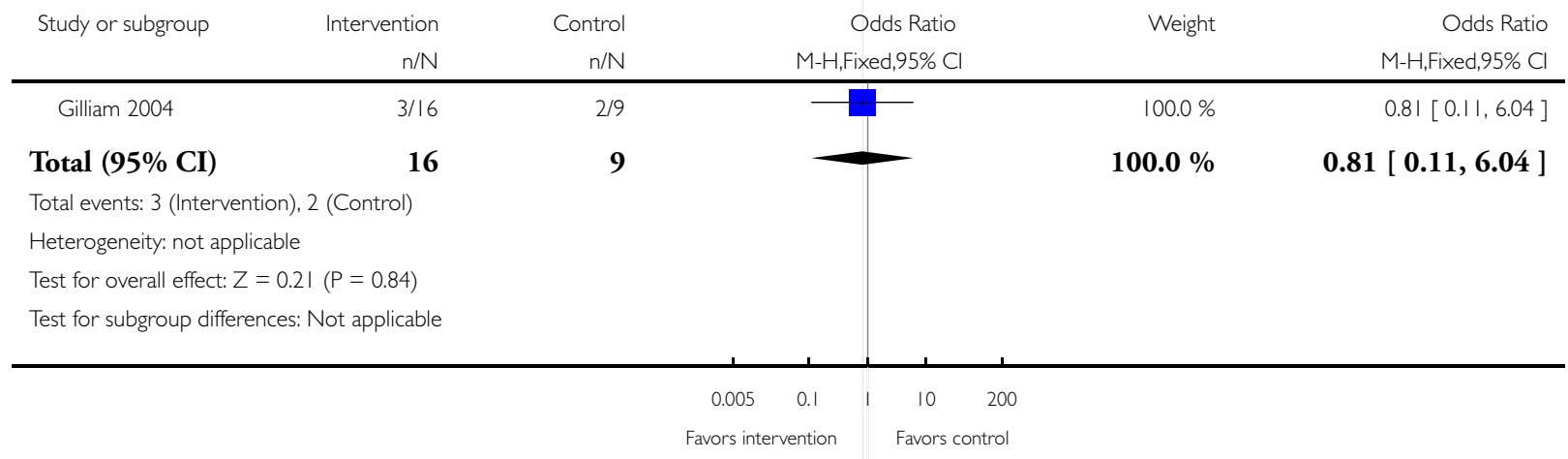


Analysis 2.I. Comparison 2 Contraceptive information (one time): physician counseling versus video versus pamphlet, Outcome I Satisfied with 'counseling' after the session: video versus physician.

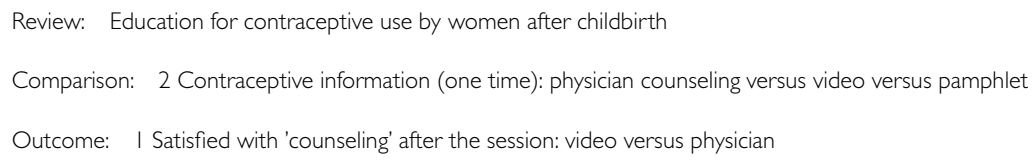

\begin{tabular}{|c|c|c|c|c|c|}
\hline \multirow[t]{2}{*}{ Study or subgroup } & Experimental & Control & Odds Ratio & Weight & Odds Ratio \\
\hline & $\mathrm{n} / \mathrm{N}$ & $\mathrm{n} / \mathrm{N}$ & M-H,Fixed,95\% Cl & & M-H,Fixed,95\% Cl \\
\hline Proctor 2006 & $105 / 117$ & $98 / 101$ & - & $100.0 \%$ & $0.27[0.07,0.98]$ \\
\hline Total (95\% CI) & 117 & 101 & & $100.0 \%$ & $0.27[0.07,0.98]$ \\
\hline
\end{tabular}

Total events: 105 (Experimental), 98 (Control)

Heterogeneity: not applicable

Test for overall effect: $Z=1.99(P=0.046)$

Test for subgroup differences: Not applicable

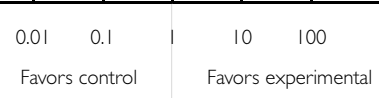

Analysis 2.2. Comparison 2 Contraceptive information (one time): physician counseling versus video versus pamphlet, Outcome 2 Satisfied with 'counseling' after the session: video versus written information.

Review: Education for contraceptive use by women after childbirth

Comparison: 2 Contraceptive information (one time): physician counseling versus video versus pamphlet

Outcome: 2 Satisfied with 'counseling' after the session: video versus written information

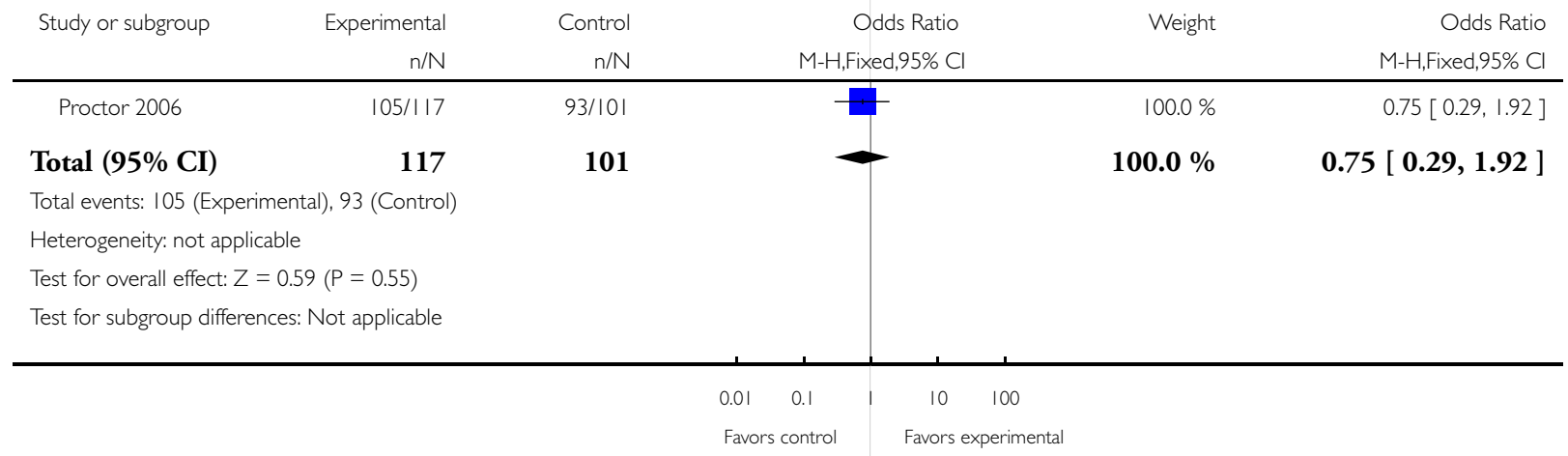


Analysis 3.I. Comparison 3 Contraceptive counseling (one time) versus no counseling, Outcome I Use of any contraceptive at 8 to $I 2$ weeks postpartum.

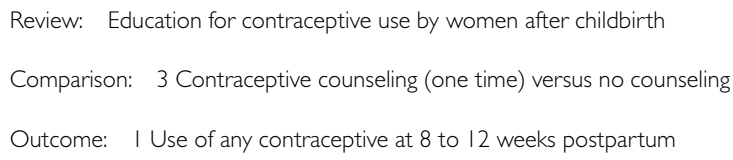

\begin{tabular}{|c|c|c|c|c|c|}
\hline \multirow[t]{2}{*}{ Study or subgroup } & Experimental & Control & Odds Ratio & Weight & Odds Ratio \\
\hline & $\mathrm{n} / \mathrm{N}$ & $\mathrm{n} / \mathrm{N}$ & M-H,Fixed,95\% Cl & & M-H,Fixed,95\% Cl \\
\hline Saeed 2008 & |70/299 & $19 / 301$ & & $100.0 \%$ & $19.56[11.65,32.83]$ \\
\hline Total $(95 \% \mathrm{CI})$ & 299 & 301 & & $100.0 \%$ & $19.56[11.65,32.83]$ \\
\hline
\end{tabular}

Total events: 170 (Experimental), 19 (Control)

Heterogeneity: not applicable

Test for overall effect: $Z=11.25(P<0.00001)$

Test for subgroup differences: Not applicable

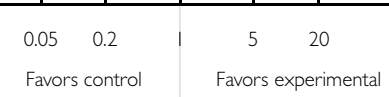

Analysis 3.2. Comparison 3 Contraceptive counseling (one time) versus no counseling, Outcome 2 Choice of modern contraceptive (using or plan to use) at 8 to $I 2$ weeks postpartum.

Review: Education for contraceptive use by women after childbirth

Comparison: 3 Contraceptive counseling (one time) versus no counseling

Outcome: 2 Choice of modern contraceptive (using or plan to use) at 8 to 12 weeks postpartum

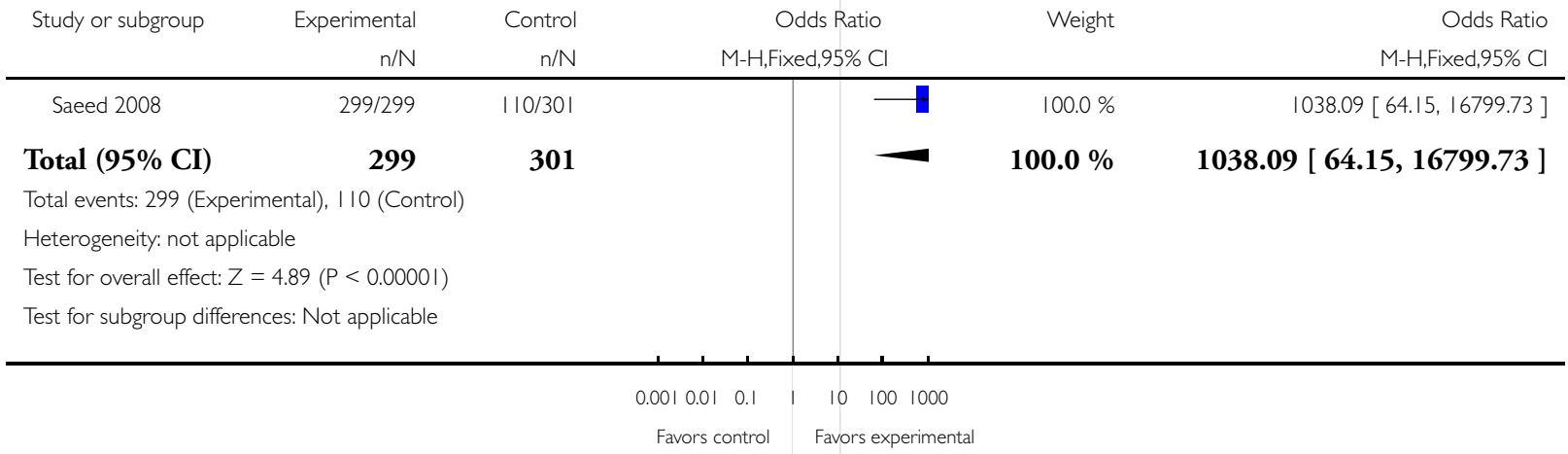


Analysis 4.I. Comparison 4 Health education including contraception: immediate, later, and no session, Outcome I Use of contraception at 3 months: immediate session versus no immediate session.

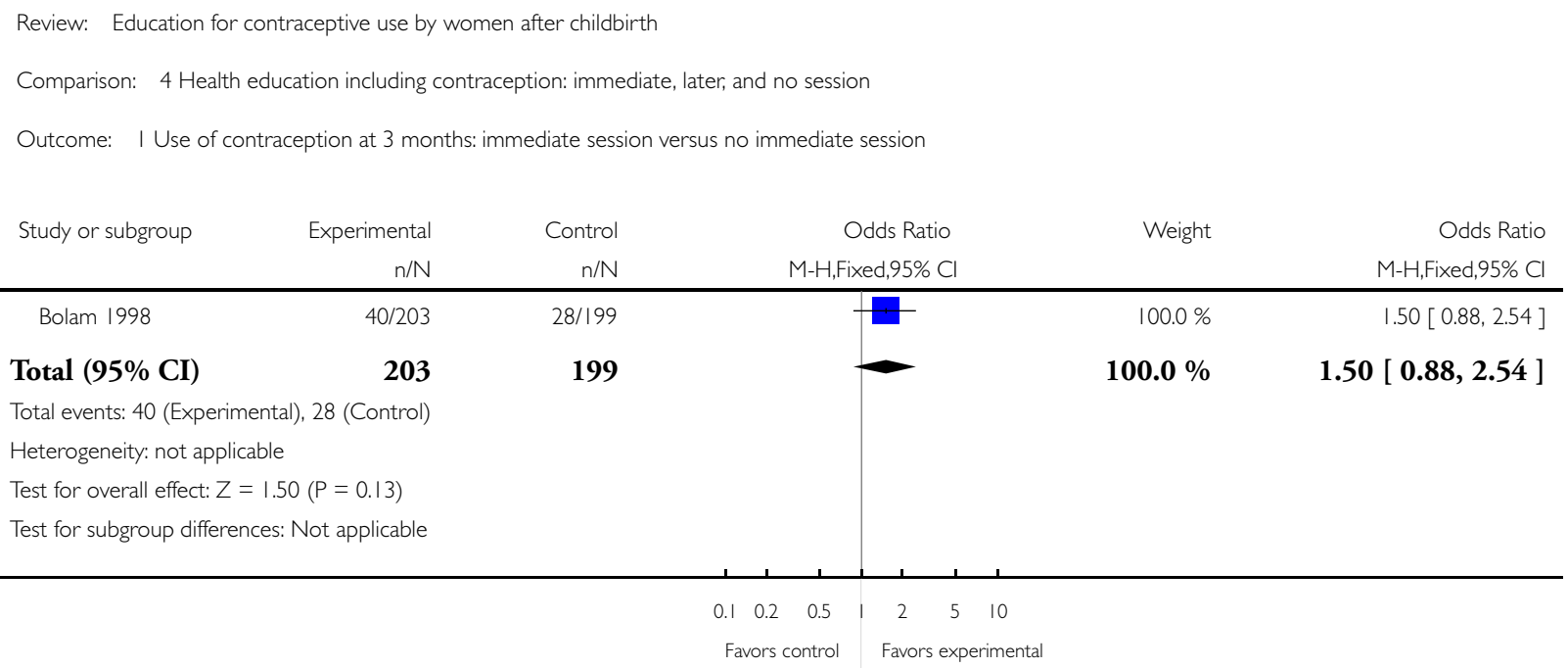

Analysis 4.2. Comparison 4 Health education including contraception: immediate, later, and no session, Outcome 2 Use of contraception at 6 months: immediate session versus no immediate session.

Review: Education for contraceptive use by women after childbirth

Comparison: 4 Health education including contraception: immediate, later, and no session

Outcome: 2 Use of contraception at 6 months: immediate session versus no immediate session

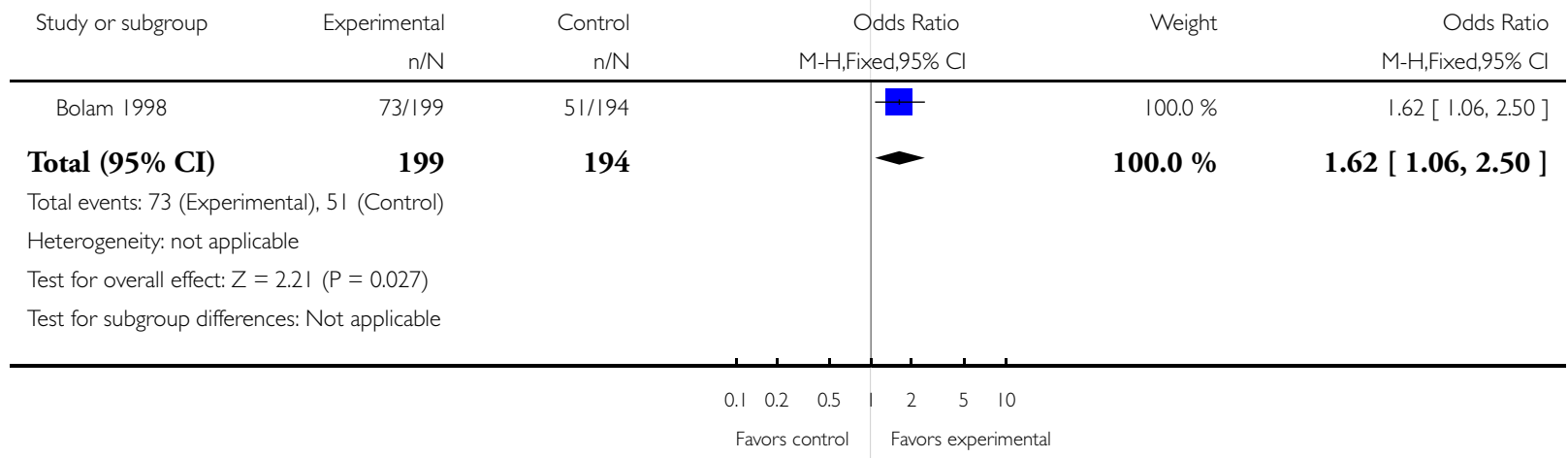


Analysis 4.3. Comparison 4 Health education including contraception: immediate, later, and no session, Outcome 3 Use of contraception at 6 months: immediate plus later sessions versus immediate session.

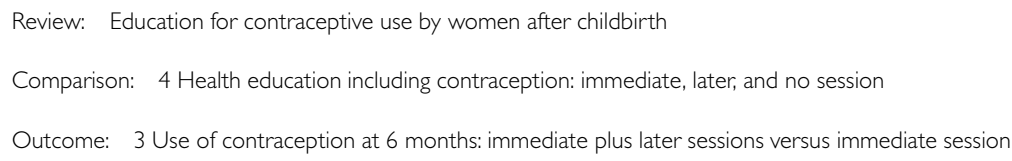

\begin{tabular}{|c|c|c|c|c|c|}
\hline \multirow[t]{2}{*}{ Study or subgroup } & Experimental & Control & Odds Ratio & Weight & Odds Ratio \\
\hline & $\mathrm{n} / \mathrm{N}$ & $\mathrm{n} / \mathrm{N}$ & M-H,Fixed,95\% Cl & & M-H,Fixed,95\% Cl \\
\hline Bolam 1998 & $33 / 95$ & $40 / 104$ & & $100.0 \%$ & $0.85[0.48,1.52]$ \\
\hline
\end{tabular}

$\begin{array}{lllll}\text { Total }(95 \% \text { CI }) & 95 & 104 & 100.0 \% & 0.85[0.48,1.52]\end{array}$

Total events: 33 (Experimental), 40 (Control)

Heterogeneity: not applicable

Test for overall effect: $Z=0.54(P=0.59)$

Test for subgroup differences: Not applicable

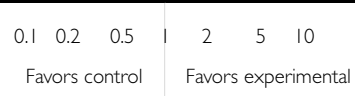

Analysis 4.4. Comparison 4 Health education including contraception: immediate, later, and no session, Outcome 4 Use of contraception at 6 months: later session versus no session.

Review: Education for contraceptive use by women after childbirth

Comparison: 4 Health education including contraception: immediate, later, and no session

Outcome: 4 Use of contraception at 6 months: later session versus no session

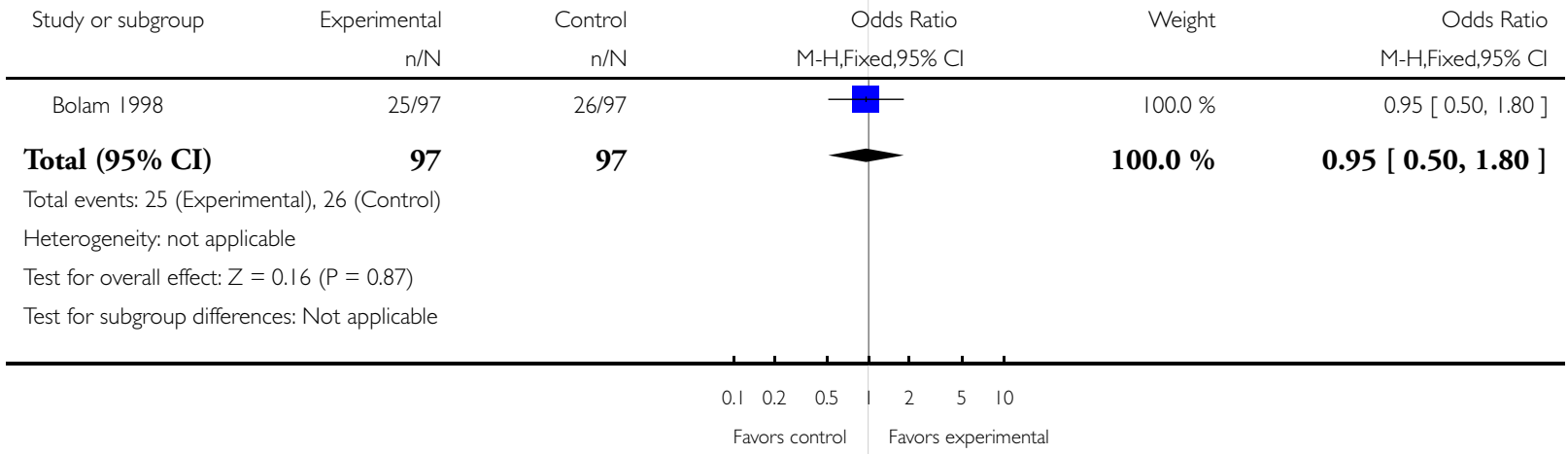


Analysis 4.5. Comparison 4 Health education including contraception: immediate, later, and no session, Outcome 5 Exclusive breastfeeding at 3 months: immediate session versus no immediate session.

Review: Education for contraceptive use by women after childbirth

Comparison: 4 Health education including contraception: immediate, later, and no session

Outcome: 5 Exclusive breastfeeding at 3 months: immediate session versus no immediate session

\begin{tabular}{|c|c|c|c|c|c|}
\hline \multirow[t]{2}{*}{ Study or subgroup } & Experimental & Control & Odds Ratio & Weight & Odds Ratio \\
\hline & $\mathrm{n} / \mathrm{N}$ & $\mathrm{n} / \mathrm{N}$ & M-H,Fixed,95\% Cl & & M-H,Fixed,95\% Cl \\
\hline Bolam 1998 & $120 / 204$ & $117 / 199$ & & $100.0 \%$ & $1.00[0.67,1.49]$ \\
\hline
\end{tabular}

Total (95\% CI) $\quad 204$

199

$100.0 \%$

$1.00[0.67,1.49]$

Total events: 120 (Experimental), I 17 (Control)

Heterogeneity: not applicable

Test for overall effect: $Z=0.01(P=1.0)$

Test for subgroup differences: Not applicable

$\begin{array}{cccc}0.5 & 0.7 & 1 & 1.5 \\ \text { Favors control } & & \text { Favors experimental }\end{array}$

Analysis 4.6. Comparison 4 Health education including contraception: immediate, later, and no session, Outcome 6 Exclusive breastfeeding >= 5 months: immediate session versus no immediate session.

Review: Education for contraceptive use by women after childbirth

Comparison: 4 Health education including contraception: immediate, later, and no session

Outcome: 6 Exclusive breastfeeding $>=5$ months: immediate session versus no immediate session

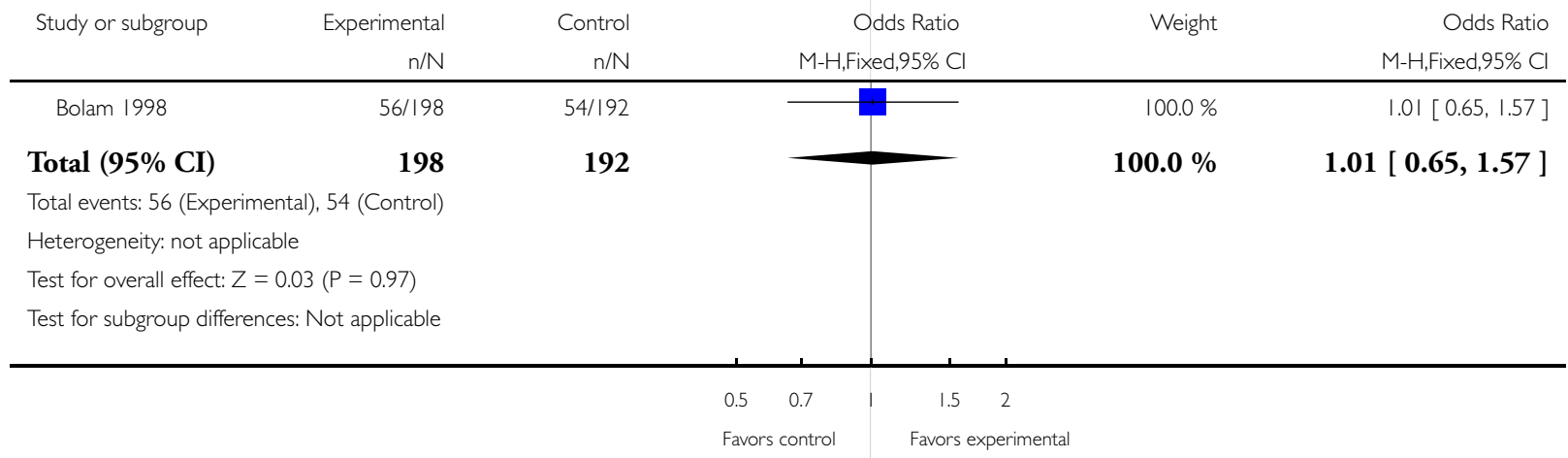


Analysis 4.7. Comparison 4 Health education including contraception: immediate, later, and no session, Outcome 7 Exclusive breastfeeding >= 5 months: immediate and later sessions versus immediate session only.

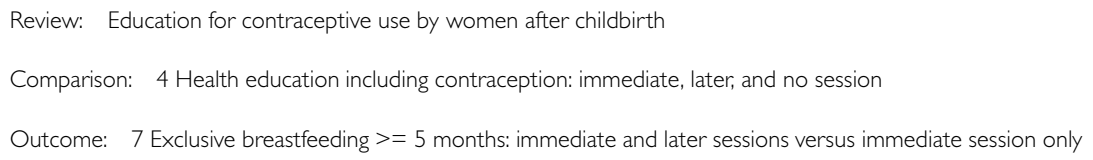

\begin{tabular}{ccccc} 
Study or subgroup & $\begin{array}{r}\text { Experimental } \\
\mathrm{n} / \mathrm{N}\end{array}$ & $\begin{array}{r}\text { Control } \\
\mathrm{n} / \mathrm{N}\end{array}$ & $\begin{array}{c}\text { Odds Ratio } \\
\text { M-H,Fixed,95\% Cl }\end{array}$ & $\begin{array}{c}\text { Weight } \\
\mathrm{M}-\mathrm{H}, \mathrm{Fixed}, 95 \% \mathrm{Cl}\end{array}$ \\
\hline Bolam 1998 & $31 / 94$ & $25 / \mathrm{l} 04$ & $\longrightarrow$ & $100.0 \%$
\end{tabular}

$\begin{array}{lllll}\text { Total }(95 \% \text { CI }) & 94 & 104 & 100.0 \% & 1.55[0.83,2.90]\end{array}$

Total events: 31 (Experimental), 25 (Control)

Heterogeneity: not applicable

Test for overall effect: $Z=1.39(P=0.16)$

Test for subgroup differences: Not applicable

$\begin{array}{cccc}0.5 & 0.7 & 1 & 1.5 \\ \text { Favors control } & & \text { Favors experimental }\end{array}$

Analysis 4.8. Comparison 4 Health education including contraception: immediate, later, and no session, Outcome 8 Exclusive breastfeeding >= 5 months: later session versus no session.

Review: Education for contraceptive use by women after childbirth

Comparison: 4 Health education including contraception: immediate, later, and no session

Outcome: 8 Exclusive breastfeeding $>=5$ months: later session versus no session

\begin{tabular}{|c|c|c|c|c|c|c|c|}
\hline \multirow[t]{2}{*}{ Study or subgroup } & Experimental & \multirow{2}{*}{$\begin{array}{r}\text { Control } \\
n / N\end{array}$} & \multicolumn{3}{|r|}{ Odds Ratio } & \multirow[t]{2}{*}{ Weight } & \multirow{2}{*}{$\begin{array}{r}\text { Odds Ratio } \\
\mathrm{M}-\mathrm{H}, \text { Fixed,95\% Cl }\end{array}$} \\
\hline & $\mathrm{n} / \mathrm{N}$ & & & & Fixed,95\% Cl & & \\
\hline Bolam 1998 & $27 / 94$ & $27 / 98$ & & & & $100.0 \%$ & $1.06[0.56,1.99]$ \\
\hline Total (95\% CI) & 94 & 98 & & & & $100.0 \%$ & $1.06[0.56,1.99]$ \\
\hline \multicolumn{8}{|c|}{ Total events: 27 (Experimental), 27 (Control) } \\
\hline \multicolumn{8}{|c|}{ Heterogeneity: not applicable } \\
\hline \multicolumn{8}{|c|}{ Test for overall effect: $Z=0.18(P=0.86)$} \\
\hline \multicolumn{8}{|c|}{ Test for subgroup differences: Not applicable } \\
\hline & & & 0.5 & 0.7 & 1.5 & 2 & \\
\hline & & & Favo & contr & Favor & perimental & \\
\hline
\end{tabular}


Analysis 5.I. Comparison 5 Special postpartum care (including contraception) versus routine services (multiple well-baby contacts), Outcome I Repeat pregnancy (self-report) by 18 months.

Review: Education for contraceptive use by women after childbirth

Comparison: 5 Special postpartum care (including contraception) versus routine services (multiple well-baby contacts)

Outcome: I Repeat pregnancy (self-report) by 18 months

\begin{tabular}{|c|c|c|c|c|c|}
\hline \multirow[t]{2}{*}{ Study or subgroup } & Experimental & Control & Odds Ratio & Weight & Odds Ratio \\
\hline & $n / N$ & $\mathrm{n} / \mathrm{N}$ & M-H,Fixed,95\% Cl & & M-H,Fixed,95\% Cl \\
\hline O'Sullivan 1992 & $13 / 108$ & $32 / 113$ & +1 & $100.0 \%$ & $0.35[0.17,0.70]$ \\
\hline Total (95\% CI) & 108 & 113 & & $100.0 \%$ & $0.35[0.17,0.70]$ \\
\hline
\end{tabular}

Total events: 13 (Experimental), 32 (Control)

Heterogeneity: not applicable

Test for overall effect: $Z=2.93$ ( $P=0.0034$ )

Test for subgroup differences: Not applicable

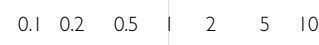

Favors experimental Favors control

Analysis 6.I. Comparison 6 Home visiting: structured versus routine, Outcome I Effective contraception use at 6 months.

Review: Education for contraceptive use by women after childbirth

Comparison: 6 Home visiting: structured versus routine

Outcome: I Effective contraception use at 6 months

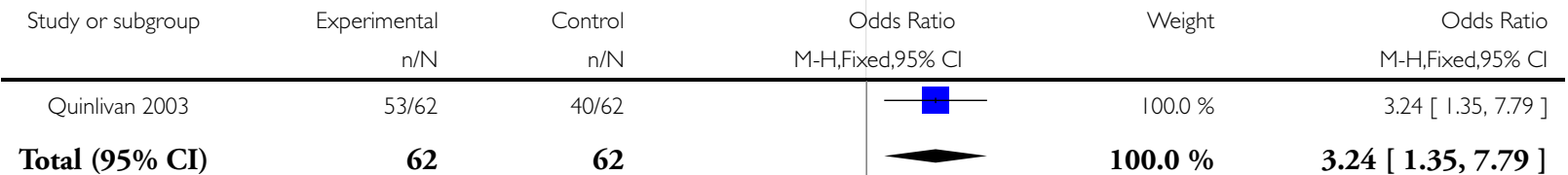

Total events: 53 (Experimental), 40 (Control)

Heterogeneity: not applicable

Test for overall effect: $Z=2.63(P=0.0087)$

Test for subgroup differences: Not applicable

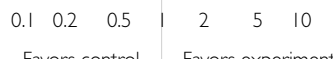

Favors control Favors experimental 
Analysis 7.I. Comparison 7 Home-based mentoring (multiple visits) versus usual care, Outcome I Second birth by $\mathbf{2 4}$ months.

\begin{tabular}{|c|c|c|c|c|c|}
\hline \multicolumn{6}{|c|}{ Comparison: 7 Home-based mentoring (multiple visits) versus usual care } \\
\hline \multicolumn{6}{|c|}{ Outcome: I Second birth by 24 months } \\
\hline \multirow[t]{2}{*}{ Study or subgroup } & Treatment & Control & Odds Ratio & Weight & Odds Ratio \\
\hline & $\mathrm{n} / \mathrm{N}$ & $\mathrm{n} / \mathrm{N}$ & M-H,Fixed,95\% Cl & & M-H,Fixed,95\% Cl \\
\hline Black 2006 & $8 / 70$ & $19 / 79$ & + & $100.0 \%$ & $0.41[0.17,1.00]$ \\
\hline Total $(95 \% \mathrm{CI})$ & 70 & 79 & 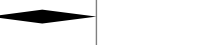 & $100.0 \%$ & $0.41[0.17,1.00]$ \\
\hline \multicolumn{6}{|c|}{ Total events: 8 (Treatment), 19 (Control) } \\
\hline \multicolumn{6}{|c|}{ Heterogeneity: not applicable } \\
\hline \multicolumn{6}{|c|}{ Test for overall effect: $Z=1.96(P=0.050)$} \\
\hline Test for subgroup diff & Jot applicable & & & & \\
\hline
\end{tabular}


Analysis 8.I. Comparison 8 Computer-assisted motivational interviewing (CAMI) with parenting curriculum versus CAMI-only versus usual care, Outcome I Repeat birth by 24 months.

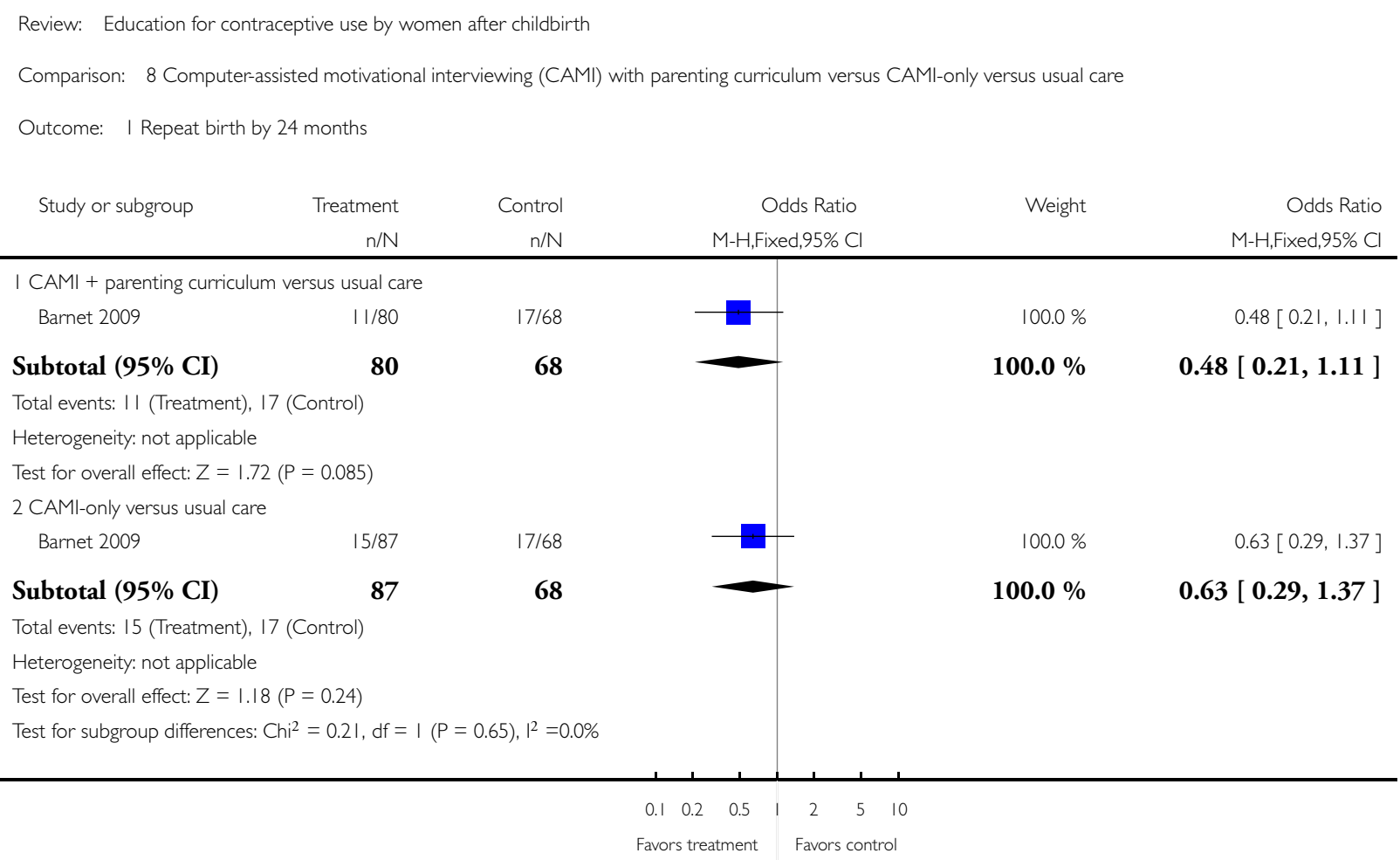


Analysis 9.1. Comparison 9 Phone counseling versus usual services, Outcome I Repeat pregnancy by 24 months.

Review: Education for contraceptive use by women after childbirth

Comparison: 9 Phone counseling versus usual services

Outcome: I Repeat pregnancy by 24 months

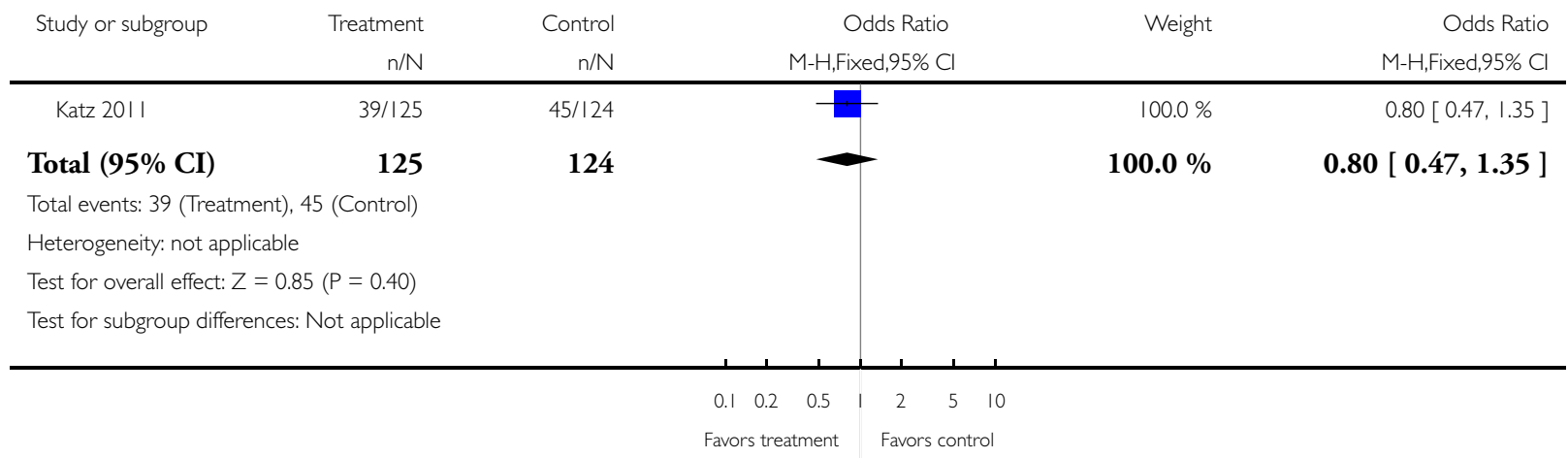

Analysis 10.I. Comparison 10 Home visiting: four visits versus one visit versus usual care, Outcome I Contraception use at 4 months: 4 visits versus I visit.

Review: Education for contraceptive use by women after childbirth

Comparison: 10 Home visiting: four visits versus one visit versus usual care

Outcome: I Contraception use at 4 months: 4 visits versus I visit

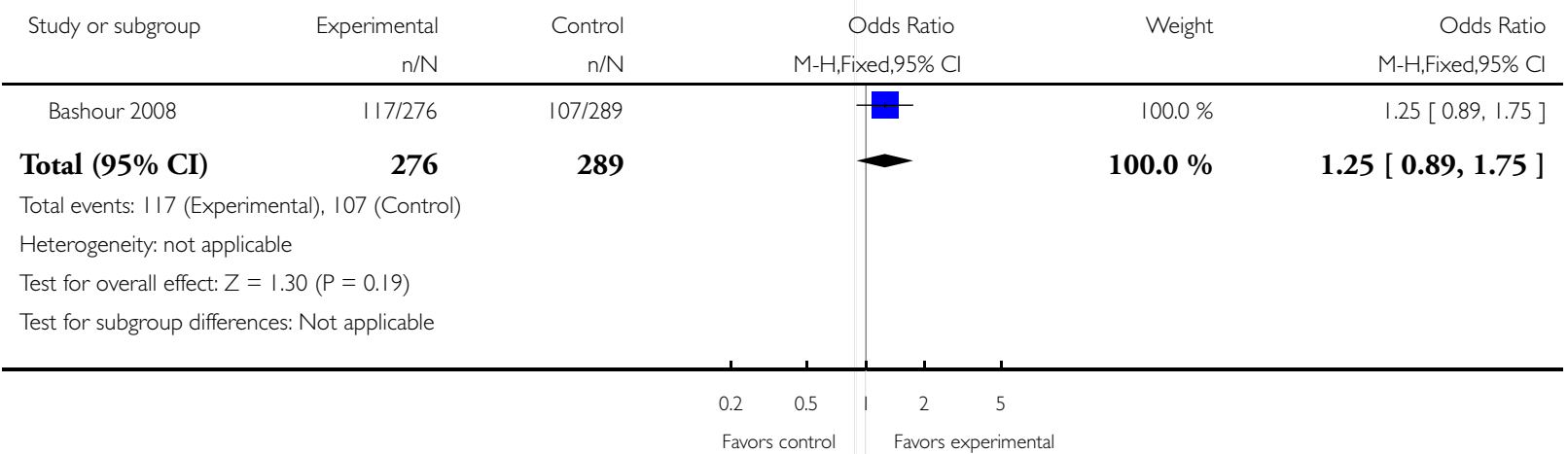


Analysis 10.2. Comparison 10 Home visiting: four visits versus one visit versus usual care, Outcome 2 Contraception use at $\mathbf{4}$ months: I visit versus usual care.

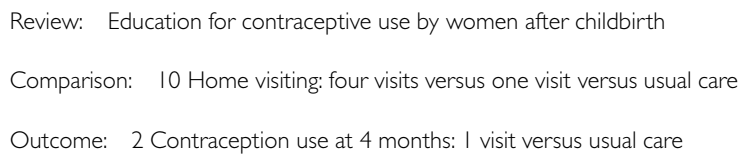

$\begin{array}{llll}\text { Total }(95 \% \mathrm{CI}) & 289 & 291 & 100.0 \%\end{array}$

Total events: 107 (Experimental), 118 (Control)

Heterogeneity: not applicable

Test for overall effect: $Z=0.87(P=0.38)$

Test for subgroup differences: Not applicable

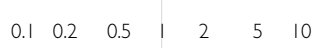

Favors control Favors experimental

Analysis 10.3. Comparison 10 Home visiting: four visits versus one visit versus usual care, Outcome 3 Pregnancy (self-reported) at 4 months postpartum: 4 visits versus I visit.

Review: Education for contraceptive use by women after childbirth

Comparison: 10 Home visiting: four visits versus one visit versus usual care

Outcome: 3 Pregnancy (self-reported) at 4 months postpartum: 4 visits versus I visit

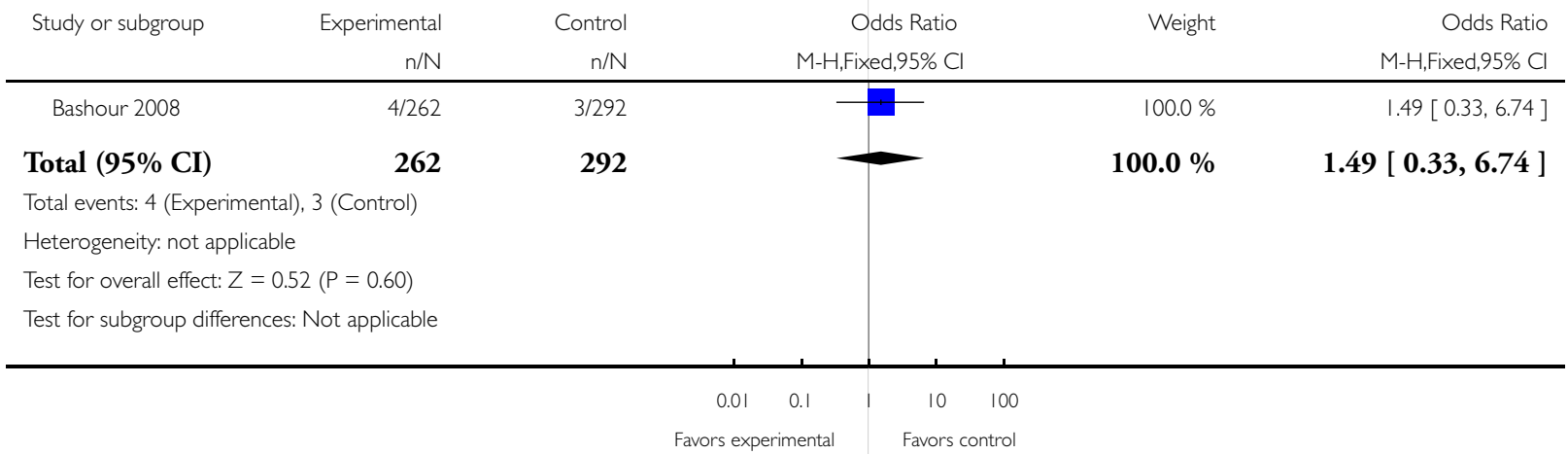




\section{Analysis 10.4. Comparison 10 Home visiting: four visits versus one visit versus usual care, Outcome 4 Pregnancy (self-reported) at 4 months postpartum: I visit versus usual care.}

Review: Education for contraceptive use by women after childbirth

Comparison: 10 Home visiting: four visits versus one visit versus usual care

Outcome: 4 Pregnancy (self-reported) at 4 months postpartum: I visit versus usual care

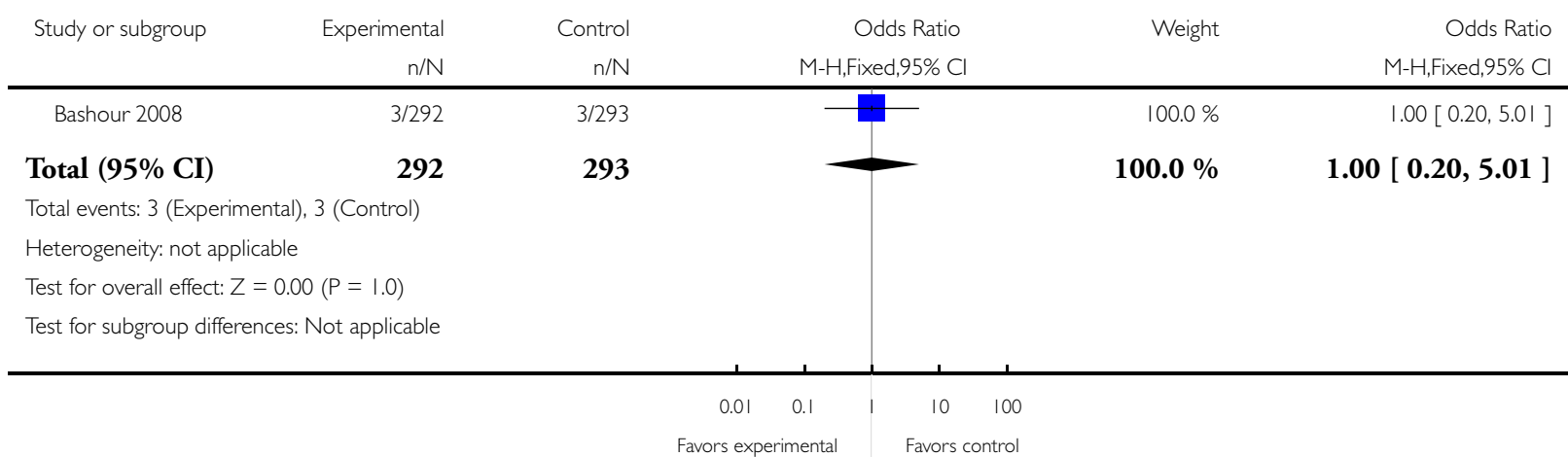

\section{A D D I TIONAL TABLES}

Table 1. Quality of intervention evidence

\begin{tabular}{|c|c|c|c|c|c|c|c|}
\hline Study & Population & $\begin{array}{l}\text { Interven- } \\
\text { tion location; } \\
\text { medium }\end{array}$ & $\begin{array}{l}\text { Intervention } \\
\text { content }\end{array}$ & $\begin{array}{l}\text { Sessions } \\
<=2\end{array}$ & $\begin{array}{l}\text { Follow-up } \\
<6 \text { months }\end{array}$ & $\begin{array}{l}\text { Intervention } \\
\text { fidelity } \\
<3 \text { items }\end{array}$ & Quality $^{1}$ \\
\hline Barnet 2009 & Adolescents & Home; CAMI & $\begin{array}{l}\text { Parenting (in- } \\
\text { cluded contra- } \\
\text { ception); case } \\
\text { management }\end{array}$ & --- & --- & --- & High (0) \\
\hline Bashour 2008 & Women & Home & $\begin{array}{l}\text { Education and } \\
\text { sup- } \\
\text { port, includ- } \\
\text { ing breastfeed- } \\
\text { ing and con- } \\
\text { traception }\end{array}$ & --- & -1 & -- & Moderate $(-1)$ \\
\hline Black 2006 & Adolescents & Home & $\begin{array}{l}\text { Parenting (in- } \\
\text { cluded contra- } \\
\text { ception) }\end{array}$ & --- & --- & --- & High (0) \\
\hline
\end{tabular}


Table 1. Quality of intervention evidence (Continued)

\begin{tabular}{|c|c|c|c|c|c|c|c|}
\hline Bolam 1998 & Women & $\begin{array}{l}\text { Hospital and } \\
\text { home }\end{array}$ & $\begin{array}{l}\text { Health educa- } \\
\text { tion, in- } \\
\text { cluding infant } \\
\text { care and fam- } \\
\text { ily planning }\end{array}$ & -1 & --- & --- & Moderate $(-1)$ \\
\hline Gilliam 2004 & $\begin{array}{l}\text { Young women } \\
\text { (age }<=25)\end{array}$ & Hospital & $\begin{array}{l}\text { Oral contra- } \\
\text { ceptive use }\end{array}$ & -1 & --- & -.- & Moderate $(-1)$ \\
\hline Katz 2011 & Adolescents & $\begin{array}{l}\text { Community; } \\
\text { cell phone }\end{array}$ & $\begin{array}{l}\text { Health } \\
\text { risks and teen } \\
\text { attitudes; in- } \\
\text { cluded repro- } \\
\text { ductive health } \\
\text { planning }\end{array}$ & -- & -- & -1 & Moderate (-1) \\
\hline $\begin{array}{l}\text { O'Sullivan } \\
1992\end{array}$ & Adolescents & $\begin{array}{l}\text { Well-baby } \\
\text { clinic }\end{array}$ & $\begin{array}{l}\text { Special well- } \\
\text { baby care }\end{array}$ & --- & -- & -- & High $(0)$ \\
\hline Proctor 2006 & Women & Hospital & $\begin{array}{l}\text { Contraceptive } \\
\text { use }\end{array}$ & -1 & -1 & --- & Low $(-2)$ \\
\hline $\begin{array}{l}\text { Quinlivan } \\
2003\end{array}$ & Adolescents & Home & $\begin{array}{l}\text { Struc- } \\
\text { tured support } \\
\text { and counsel- } \\
\text { ing }\end{array}$ & -- & -- & -1 & Moderate $(-1)$ \\
\hline Saeed 2008 & Women & Hospital & $\begin{array}{l}\text { Contraceptive } \\
\text { use }\end{array}$ & -1 & -1 & --- & Low $(-2)$ \\
\hline
\end{tabular}

Table 2. Quality of evidence

\begin{tabular}{|c|c|c|c|c|c|c|c|c|c|}
\hline Study & $\begin{array}{l}\text { Random- } \\
\text { ization; } \\
\text { allo- } \\
\text { cation con- } \\
\text { cealment }\end{array}$ & $\begin{array}{l}\text { Interven- } \\
\text { tion quality }\end{array}$ & $\begin{array}{l}\text { Outcome } \\
\text { assessment }\end{array}$ & $\begin{array}{l}\text { Losses } \\
20 \%\end{array}$ & $>$ & Other & Blinding & $\begin{array}{l}\text { Quality of evi- } \\
\text { dence }^{1}\end{array}$ & Effectiveness $^{2}$ \\
\hline Barnet 2009 & -1 & -- & -- & -- & & -- & -- & Moderate $(-1)$ & -- \\
\hline $\begin{array}{l}\text { Bashour } \\
2008\end{array}$ & -- & -.- & -1 & --- & & --- & +1 & High (0) & --- \\
\hline
\end{tabular}


Table 2. Quality of evidence (Continued)

\begin{tabular}{|c|c|c|c|c|c|c|c|c|}
\hline Black 2006 & -1 & --- & --- & -- & $-2^{a, b}$ & --- & Very low (-3) & $\begin{array}{l}\text { Fewer repeat } \\
\text { births }\end{array}$ \\
\hline Bolam 1998 & -- & --- & -1 & -1 & -- & +1 & Moderate (-1) & $\begin{array}{l}\text { Use of contra- } \\
\text { ception }\end{array}$ \\
\hline $\begin{array}{l}\text { Gilliam } \\
2004\end{array}$ & -- & -- & -- & -1 & --- & +1 & High $(0)$ & --- \\
\hline Katz 2011 & -1 & -- & -- & -- & -- & -- & Moderate (-1) & -- \\
\hline $\begin{array}{l}\text { O'Sullivan } \\
1992\end{array}$ & -1 & --- & -1 & -- & --- & -- & Low $(-2)$ & $\begin{array}{l}\text { Fewer repeat } \\
\text { pregnancies }\end{array}$ \\
\hline $\begin{array}{l}\text { Proctor } \\
2006\end{array}$ & --- & -1 & -1 & NA & $-1^{b}$ & --- & Very low (-3) & --- \\
\hline $\begin{array}{l}\text { Quinlivan } \\
2003\end{array}$ & --- & --- & -1 & -- & -- & -- & Moderate $(-1)$ & $\begin{array}{l}\text { 'Effective' use of } \\
\text { contraception }\end{array}$ \\
\hline Saeed 2008 & -1 & -1 & -1 & -- & -- & +1 & Low $(-2)$ & $\begin{array}{l}\text { Use of contra- } \\
\text { ception }\end{array}$ \\
\hline
\end{tabular}

${ }^{1}$ Quality could be high, moderate, low, or very low. We considered these RCTs to be high quality then downgraded a level for each of the following: a) no information on randomization sequence generation or allocation concealment, or no concealment; b) low intervention quality (Table 1); c) outcome assessment (no objective assessment, e.g., pregnancy test, or no structured questionnaire on contraceptive use); d) losses to follow-up > 20\%; e) other ( ${ }^{a}$ selective outcome reporting or ${ }^{b}$ exclusion after randomization). We upgraded one level if some blinding was used. Due to the types of interventions, blinding of investigators and participants to assignment was difficult although blinding of outcome assessors was more feasible.

${ }^{2}$ Evidence of difference between study groups in contraceptive use, repeat pregnancies, or repeat births.

Table 3. Intervention fidelity information

\begin{tabular}{|c|c|c|c|c|}
\hline Study & Provider credentials & Provider training & Standardized delivery & Delivery adherence \\
\hline Barnet 2009 & $\begin{array}{l}\text { African American parapro- } \\
\text { fessional women from par- } \\
\text { ticipants communities; } \\
\text { hired for empathetic qual- } \\
\text { ities, rapport with adoles- } \\
\text { cents, and knowledge of } \\
\text { the community }\end{array}$ & $\begin{array}{l}2.5 \text { days on Transthe- } \\
\text { oretical model, motiva- } \\
\text { tional interviewing (MI) } \\
\text {, and computer-assisted } \\
\text { motivational intervention } \\
\text { (CAMI) }\end{array}$ & $\begin{array}{l}\text { CAMI was structured soft- } \\
\text { ware developed for study; } \\
\text { counseling was 20-minute } \\
\text { stage-matched MI session; } \\
\text { parenting curriculum ( } \\
\text { Black 2006) }\end{array}$ & $\begin{array}{l}\text { During first } 4 \text { months of } \\
\text { program, counselors met } \\
\text { biweekly with MI supervi- } \\
\text { sor, who discussed audio- } \\
\text { tapes and provided feed- } \\
\text { back }\end{array}$ \\
\hline Bashour 2008 & Registered midwives & 5 days of special training & $\begin{array}{l}\text { Objectives listed for each } \\
\text { visit. Breastfeeding was ad- } \\
\text { dressed in visits } 2 \text { and } 3 \text {; } \\
\text { family planning in visit } 4\end{array}$ & No information \\
\hline
\end{tabular}

Education for contraceptive use by women after childbirth (Review) 
Table 3. Intervention fidelity information

(Continued)

\begin{tabular}{|c|c|c|c|c|}
\hline Black 2006 & $\begin{array}{l}2 \text { Black women, college- } \\
\text { educated, in their } 20 \text { s, sin- } \\
\text { gle mothers and living in- } \\
\text { dependently }\end{array}$ & $\begin{array}{l}\text { "Extensive" training was } \\
\text { provided }\end{array}$ & $\begin{array}{l}\text { Curricu- } \\
\text { lum with } 19 \text { lessons; order } \\
\text { could vary after } 2 \text { sessions }\end{array}$ & $\begin{array}{l}\text { Weekly supervisory ses- } \\
\text { sions }\end{array}$ \\
\hline Bolam 1998 & $\begin{array}{l}3 \text { health educators, } 2 \text { mid- } \\
\text { wives, } 1 \text { community health } \\
\text { worker }\end{array}$ & $\begin{array}{l}\text { Providers "trained" to give } \\
\text { the health education }\end{array}$ & $\begin{array}{l}\text { Format and content iden- } \\
\text { tified for sessions, includ- } \\
\text { ing key messages }\end{array}$ & $\begin{array}{l}\text { Inves- } \\
\text { tigators monitored weekly } \\
\text { and provided feedback }\end{array}$ \\
\hline Gilliam 2004 & $\begin{array}{l}\text { Resident physicians plus } \\
\text { nurses for additional coun- } \\
\text { seling }\end{array}$ & $\begin{array}{l}\text { Training session for resi- } \\
\text { dent physicians and nurses }\end{array}$ & $\begin{array}{l}\text { Researchers developed the } \\
\text { counseling } \\
\text { program, video, and pam- } \\
\text { phlet for this study. Devel- } \\
\text { opment was described }\end{array}$ & No information \\
\hline Katz 2011 & $\begin{array}{l}\text { Mas- } \\
\text { ters-level young women of } \\
\text { similar racial-ethnic back- } \\
\text { ground as the teens }\end{array}$ & No information & $\begin{array}{l}\text { Curriculum manual pro- } \\
\text { vided standardized format } \\
\text { and structure to counsel- } \\
\text { ing sessions. Teens were } \\
\text { given workbooks with vi- } \\
\text { sual material related to } \\
\text { topics }\end{array}$ & No information \\
\hline O'Sullivan 1992 & $\begin{array}{l}\text { Directed by master's pre- } \\
\text { pared nurse practitioner. } \\
\text { Providers: social worker, } \\
\text { pedi- } \\
\text { atrician and nurse practi- } \\
\text { tioners, and volunteers (for } \\
\text { health teaching) }\end{array}$ & Volunteers were "trained" & $\begin{array}{l}\text { Four goals and specific ser- } \\
\text { vices identified, as well as } \\
\text { which professionals would } \\
\text { provide each component }\end{array}$ & No information \\
\hline Proctor 2006 & Resident physicians & $\begin{array}{l}\text { Didactic session on con- } \\
\text { traceptive methods and } \\
\text { outline for talking points }\end{array}$ & $\begin{array}{l}\text { Existing materials for } 3 \text { in- } \\
\text { tervention methods were } \\
\text { based on the same content }\end{array}$ & No information \\
\hline Quinlivan 2003 & Certified midwives & No information & $\begin{array}{l}\text { Structured home visits } \\
\text { were outlined in report }\end{array}$ & No information \\
\hline Saeed 2008 & Physicians & $\begin{array}{l}\text { Providers had } 40 \text {-minute } \\
\text { training on leaflet and in- } \\
\text { terview methods }\end{array}$ & Counseling leaflet used & No information \\
\hline
\end{tabular}

Education for contraceptive use by women after childbirth (Review) 


\section{A P P E N D I C E S}

\section{Appendix I. Search 2012}

\section{MEDLINE via PubMed (0I Jan 2009 to 29 May 20 I 2)}

(“Contraception”[Mesh] OR “Contraception Behavior”[Mesh] OR “Contraceptive Agents”[Mesh] OR “Contraceptive Devices”[Mesh] OR "family planning”) AND (educat* OR counsel* OR communicat* OR “information dissemination” OR intervention* OR choice OR choose OR use) AND (“Postpartum Period”[Mesh] OR "Postnatal Care”[Mesh] OR postpartum OR post-partum OR postnatal) Limits Activated: Clinical Trial, Randomized Controlled Trial

\section{CENTRAL (2009 to 29 May 20I2)}

contracept* OR family planning in Title, Abstract or Keywords AND counsel* OR communicat* OR educat* OR information disseminat* OR intervention OR choice OR choose OR use in Title, Abstract or Keywords AND postpartum OR post-partum OR postnatal in Title, Abstract or Keywords

\section{POPLINE (2009 to 29 May 20I2)}

title/keyword -(counseling/clinic activities/counselors/family planning education/health education/population education/family planning program*/sex education/family planning center*/teaching material*/counsel*/debrief*/educat*/teach*/birth control*/ family planning) \& (postpartum program*/puerperium/postpartum women/maternal-child health service*/maternal health service*/postnatal ${ }^{*} /$ post-partum/postpartum/postpartal*/puerperium/maternity/maternal/mother*)

$\&$ (clinical trial/random*)

OR

abstract -(counseling/clinic activities/counselors/family planning education/health education/population education/family planning program*/sex education/family planning center*/teaching material*/counsel*/debrief*/educat*/teach*/birth control*/ family planning) $\&$ (postpartum program*/puerperium/postpartum women/maternal-child health service*/maternal health service*/postnatal*/postpartum/postpartum/postpartal*/puerperium/maternity/maternal/mother*)

$\&$ (clinical trial/random*)

\section{CINAHL (through Ebscohost) (2009 to 30 May 20I2)}

counseling or sex education or client education or health promotion or teaching or counsel* ${ }^{*}$ debrief* or educat* or teach* $^{*}$ AND

postnatal period or postnatal* or post?natal* or postpartum or post?partum or post-partum or postpartal* or maternity or maternal or mother* or puerperium

AND

birth control or contraceptive devices or family planning or sterilization?sex or (family n6 planning) or contracept* or (pregnan* $\mathrm{n} 6$ prevent*) or (birth n6 control)

AND

clinical trial* or clinical stud ${ }^{*}$ or randomized n controlled $\mathrm{n}$ trial* ${ }^{*}$ or randomised n controlled $\mathrm{n}$ trial* ${ }^{*}$ random*

\section{PsycINFO (2009 to 30 May 2012)}

(counseling or sex education or client education or health promotion or teaching or counsel* or debrief* or educat* or teach*) AND (postnatal period or postnatal* or post?natal* or postpartum or post?partum or post-partum or postpartal* or maternity or maternal or mother* or puerperium) AND (birth control or contraceptive device* or contraceptive agent* or "family planning" or sterilization?sex or family N6 planning or contracept* or pregnan* N6 prevent* or birth N6 control) AND (clinical trial* or clinical stud* or randomized $\mathrm{N} 1$ controlled N1 trial* or randomised N1 controlled N1 trial* or random*)

Education for contraceptive use by women after childbirth (Review) 


\section{ClinicalTrials.gov (29 May 20I2)}

Search terms: (postpartum OR post-partum OR postnatal OR matern* OR mothers) AND (contraceptive OR contraception OR births OR home visit* OR family planning)

Conditions: NOT (preterm OR low birth weight OR HIV OR pregnancy OR labor OR congenital OR influenza OR drug)

Interventions: NOT (insertion OR supplement* OR caesarean)

\section{ICTRP (29 May 20I2)}

Title: postpartum OR post-partum OR postnatal OR maternal OR maternity OR mothers

Condition: NOT (preterm OR low birth weight OR HIV OR pregnancy)

Intervention: (contraceptive OR contraception OR births OR home visits OR family planning)

\section{Appendix 2. Search 2009}

\section{MEDLINE via Pubmed (20 May 2009)}

(“Contraception”[Mesh] OR “Contraception Behavior”[Mesh] OR “Contraceptive Agents”[Mesh] OR "Contraceptive Devices”[Mesh] OR "family planning”) AND (educat* OR counsel* OR communicat* OR “information dissemination” OR intervention* OR choice OR choose OR use) AND ("Postpartum Period”[Mesh] OR "Postnatal Care"[Mesh] OR postpartum OR post-partum OR postnatal) AND (Clinical Trial[ptyp] OR Randomized Controlled Trial[ptyp] OR Clinical Trial, Phase I[ptyp] OR Clinical Trial, Phase II[ptyp] OR Clinical Trial, Phase III[ptyp] OR Clinical Trial, Phase IV[ptyp] OR Comparative Study[ptyp] OR Controlled Clinical Trial[ptyp] OR Evaluation Studies[ptyp])

\section{CENTRAL (20 May 2009)}

contracept* OR family planning in Title, Abstract or Keywords AND counsel* OR communicat* OR educat* OR information disseminat* OR intervention OR choice OR choose OR use in Title, Abstract or Keywords AND postpartum OR post-partum OR postnatal in Title, Abstract or Keywords

\section{EMBASE (19 Feb 2009)}

1. $\exp$ COUNSELING/

2. exp HEALTH EDUCATION/

3. SEXUAL EDUCATION/ or TEACHING/ or PATIENT SATISFACTION/

4. (counsel\$ or debrief\$ or educat\$ or teach\$).ti,ab.

5. 1 or 2 or 3 or 4

6. $\exp$ POSTNATAL CARE/

7. $\exp$ MATERNAL CARE/

8. MATERNAL BEHAVIOR/

9. HOSPITAL DISCHARGE/

10. (postnatal\$ or postpartum or post-partum or post partum or postpartal\$).ti,ab.

11. (maternity or maternal or mother\$).ti,ab.

12. puerperium.ti,ab.

13. 6 or 7 or 8 or 9 or 10 or 11 or 12

14. exp BIRTH CONTROL/ or exp CONTRACEPTION/

15. exp CONTRACEPTIVE DEVICE or exp CONTRACEPTIVE AGENT/

16. exp GESTAGEN/

17. ((family adj6 planning) or contracept\$ or (pregnan\$ adj6 prevent\$)).ti,ab.

18. (birth adj6 control).ti,ab.

19. 14 or 15 or 16 or 17 or 18

20.5 and 13 and 19

Education for contraceptive use by women after childbirth (Review)

Copyright ( 2012 The Cochrane Collaboration. Published by John Wiley \& Sons, Ltd. 
21. CLINICAL STUDY/ or CLINICAL ARTICLE/ or CASE CONTROL STUDY/ or LONGITUDINAL STUDY/ or MAJOR CLINICAL STUDY/ or PROSPECTIVE STUDY/ or CLINICAL TRIAL/ or MULTICENTER STUDY/ or PHASE 3 CLINICAL TRIAL/ or PHASE 4 CLINICAL TRIAL/ or RANDOMIZED CONTROLLED TRIAL/ or CONTROLLED STUDY/ or CROSSOVER PROCEDURE/ or DOUBLE BLIND PROCEDURE/ or INTERMETHOD COMPARISON/ or SINGLE BLIND PROCEDURE/ or PLACEBO/

22. (allocat $\$$ or assign $\$$ or compar $\$$ or control $\$$ or cross over $\$$ or crossover $\$$ or factorial $\$$ or latin square or latin-square or followup or follow up or placebo $\$$ or prospective $\$$ or random $\$$ or trial $\$$ or versus or vs).ti,ab.

23. (clinic $\$$ adj25 study).ti,ab.

24. (clinic $\$$ adj25 trial).ti,ab.

25. (singl $\$$ or doubl $\$$ or trebl $\$$ or tripl $\$$ ) adj25 (blind $\$$ or mask $\$)$ ).ti,ab.

26. 21 or 22 or 23 or 24 or 25

27. NONHUMAN/ OR ANIMAL/ OR ANIMAL EXPERIMENT/

28. HUMAN/ AND (NONHUMAN/ OR ANIMAL OR ANIMAL EXPERIMENTATION/)

29. 27 not 28

30. 26 not 29

31.20 and 30

\section{POPLINE (19 Feb 2009)}

title/keyword -(counseling/clinic activities/counselors/family planning education/health education/population education/family planning program*/sex education/family planning center*/teaching material*/counsel*/debrief*/educat*/teach*/birth control*/ family planning) \& (postpartum program*/puerperium/postpartum women/maternal-child health service*/maternal health service*/postnatal ${ }^{*} /$ post-partum/postpartum/postpartal ${ }^{*} /$ puerperium/maternity/maternal/mother ${ }^{*}$ )

$\&$ (clinical trial/random*)

OR

abstract -(counseling/clinic activities/counselors/family planning education/health education/population education/family planning program*/sex education/family planning center*/teaching material*/counsel*/debrief*/educat*/teach*/birth control*/ family planning) $\&$ (postpartum program*/puerperium/postpartum women/maternal-child health service*/maternal health service*/postnatal*/postpartum/postpartum/postpartal*/puerperium/maternity/maternal/mother*)

$\&\left(\right.$ clinical trial/random* $\left.{ }^{*}\right)$

\section{CINAHL (19 Feb 2009)}

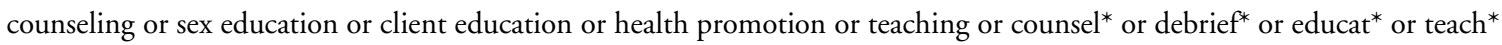
AND

postnatal period or postnatal* or post?natal* or postpartum or post?partum or post-partum or postpartal* or maternity or maternal or mother* or puerperium

AND

birth control or contraceptive devices or family planning or sterilization?sex or (family n6 planning) or contracept* or (pregnan* n6 prevent*) or (birth n6 control)

AND

clinical trial* or clinical stud* or randomized $\mathrm{n}$ controlled $\mathrm{n}$ trial* or randomised $\mathrm{n}$ controlled $\mathrm{n}$ trial* ${ }^{*}$ random*

\section{PsycINFO (19 Feb 2009)}

(counseling or sex education or client education or health promotion or teaching or counsel* or debrief* or educat* or teach*) AND (postnatal period or postnatal* or post?natal* or postpartum or post?partum or post-partum or postpartal* or maternity or maternal or mother* or puerperium) AND (birth control or contraceptive device* or contraceptive agent* or "family planning" or sterilization?sex or family N6 planning or contracept* or pregnan* N6 prevent* or birth N6 control) AND (clinical trial* or clinical stud* or randomized $\mathrm{N} 1$ controlled N1 trial* or randomised N1 controlled N1 trial* or random*)

Education for contraceptive use by women after childbirth (Review)

Copyright $\odot 2012$ The Cochrane Collaboration. Published by John Wiley \& Sons, Ltd. 


\section{ClinicalTrials.gov (16 Jun 2009)}

Search terms: postpartum OR post-partum OR postnatal OR matern* OR mothers

Conditions: NOT (preterm OR low birth weight OR HIV OR pregnancy)

Interventions: (contraceptive OR contraception OR births OR home visit* OR family planning) NOT (insertion OR supplement* OR caesarean)

\section{ICTRP (16 Jun 2009)}

Title: postpartum OR post-partum OR postnatal OR maternal OR maternity OR mothers Condition: NOT (preterm OR low birth weight OR HIV OR pregnancy)

Intervention: (contraceptive OR contraception OR births OR home visits OR family planning)

\section{Appendix 3. Search 2001}

\section{MEDLINE OvidWeb (1966-200 I Aug) and The Cochrane Controlled Trials Register}

1. COUNSELING/

2. SEX COUNSELING/

3. PATIENT EDUCATION/

4. HEALTH EDUCATION/

5. HEALTH PROMOTION/

6. $\exp$ TEACHING/

7. (counsel $\$$ or debrief $\$$ or educat $\$$ or teach $\$$ ).ti,ab.

8. 1 or 2 or 3 or 4 or 5 or 6 or 7

9. POSTNATAL CARE/

10. $\exp$ PUERPERIUM/

11. MATERNAL HEALTH SERVICES/

12. MATERNAL-CHILD HEALTH CENTERS/

13. MATERNAL BEHAVIOR/

14. PATIENT DISCHARGE/

15. (postnatal $\$$ or post-partum or postpartum or post partum or postpartal $\$$ ).ti,ab.

16. (maternity or maternal or mother\$).ti,ab.

17. puerperium.ti,ab.

18. discharg\$.ti,ab.

19. 9 or 10 or 11 or 12 or 13 or 14 or 15 or 16 or 17 or 18

20. CONTRACEPTION BEHAVIOR/

21. exp CONTRACEPTION/

22. $\exp$ CONTRACEPTIVE AGENTS/

23. exp CONTRACEPTIVE DEVICES/

24. exp FAMILY PLANNING/

25. FAMILY PLANNING POLICY/

26. POPULATION CONTROL/

27. ((family adj6 planning) or contracept $\$$ or (pregnan $\$$ adj6 prevent $\$)$ ).ti,ab.

28. (birth adj6 control).ti,ab.

29.20 or 21 or 22 or 23 or 24 or 25 or 26 or 27 or 28

30. 8 and 19 and 29

31. 30 and human/

32. RANDOMIZED CONTROLLED TRIAL.pt.

33. CONTROLLED CLINICAL TRIAL.pt.

34. RANDOMIZED CONTROLLED TRIALS/

35. RANDOM ALLOCATION/

Education for contraceptive use by women after childbirth (Review)

Copyright $\odot 2012$ The Cochrane Collaboration. Published by John Wiley \& Sons, Ltd. 
36. DOUBLE-BLIND METHOD/

37. SINGLE-BLIND METHOD/

38. CLINICAL TRIAL.pt.

39. $\exp$ CLINICAL TRIALS

40. (clin\$ adj25 trial\$).ti,ab.

41. ((singl\$ or doubl\$ or trebl\$ or tripl\$) adj25 (blind\$ or mask\$)).ti,ab.

42. PLACEBOS/

43. (placebo $\$$ or random $\$$ ).ti,ab.

44. RESEARCH DESIGN/

45. COMPARATIVE STUDY/

46. exp EVALUATION STUDIES/

47. exp CASE-CONTROL STUDIES/ or exp COHORT STUDIES/

48. (control\$ or prospective\$ or volunteer\$).ti,ab.

49. (latin square or latin-square).ti,ab.

50. (cross-over\$ or cross over\$).ti,ab.

51. factorial\$.ti,ab.

52. CROSS-OVER STUDIES/

53.32 or 33 or 34 or 35 or 36 or 37 or 38 or 39 or 40 or 41 or 42 or 43 or 44 or 45 or 46 or 47 or 48 or 49 or 50 or 51 or 52

54. (animal not (human and animal)).sh.

55.53 not 54

56. 55 and 31

N.B. for searching The Cochrane Controlled Trials Register please substitute “*” for “\$” and "near” for "adj”

\section{EMBASE, OvidWeb (1980-200 I Aug)}

1. $\exp$ COUNSELING/

2. exp HEALTH EDUCATION/

3. SEXUAL EDUCATION/ or TEACHING/ or PATIENT SATISFACTION/

4. (counsel\$ or debrief\$ or educat\$ or teach\$).ti,ab.

5. 1 or 2 or 3 or 4

6. $\exp$ POSTNATAL CARE/

7. $\exp$ MATERNAL CARE/

8. MATERNAL BEHAVIOR/

9. HOSPITAL DISCHARGE/

10. (postnatal\$ or postpartum or post-partum or post partum or postpartal\$).ti,ab.

11. (maternity or maternal or mother\$).ti,ab.

12. puerperium.ti,ab.

13. 6 or 7 or 8 or 9 or 10 or 11 or 12

14. $\exp$ BIRTH CONTROL/ or exp CONTRACEPTION/

15. exp CONTRACEPTIVE DEVICE or exp CONTRACEPTIVE AGENT/

16. exp GESTAGEN/

17. ((family adj6 planning) or contracept\$ or (pregnan\$ adj6 prevent\$)).ti,ab.

18. (birth adj6 control).ti,ab.

19. 14 or 15 or 16 or 17 or 18

20.5 and 13 and 19

21. CLINICAL STUDY/ or CLINICAL ARTICLE/ or CASE CONTROL STUDY/ or LONGITUDINAL STUDY/ or MAJOR CLINICAL STUDY/ or PROSPECTIVE STUDY/ or CLINICAL TRIAL/ or MULTICENTER STUDY/ or PHASE 3 CLINICAL TRIAL/ or PHASE 4 CLINICAL TRIAL/ or RANDOMIZED CONTROLLED TRIAL/ or CONTROLLED STUDY/ or CROSSOVER PROCEDURE/ or DOUBLE BLIND PROCEDURE/ or INTERMETHOD COMPARISON/ or SINGLE BLIND PROCEDURE/ or PLACEBO/

22. (allocat $\$$ or assign $\$$ or compar $\$$ or control $\$$ or cross over $\$$ or crossover $\$$ or factorial $\$$ or latin square or latin-square or followup or follow up or placebo $\$$ or prospective $\$$ or random $\$$ or trial $\$$ or versus or vs).ti,ab.

23. (clinic $\$$ adj25 study).ti,ab.

Education for contraceptive use by women after childbirth (Review)

Copyright $\odot 2012$ The Cochrane Collaboration. Published by John Wiley \& Sons, Ltd. 
24. (clinic $\$$ adj25 trial).ti,ab.

25. (singl\$ or doubl $\$$ or trebl\$ or tripl $\$$ ) adj25 (blind $\$$ or mask $\$)$ ).ti,ab.

26. 21 or 22 or 23 or 24 or 25

27. NONHUMAN/ OR ANIMAL/ OR ANIMAL EXPERIMENT/

28. HUMAN/ AND (NONHUMAN/ OR ANIMAL OR ANIMAL EXPERIMENTATION/)

29. 27 not 28

30. 26 not 29

31. 20 and 30

POPLINE (1970-200 I Aug)

1. COUNSELING/

2. CLINIC ACTIVITIES/

3. COUNSELORS/

4. FAMILY PLANNING EDUCATION/

5. HEALTH EDUCATION/

6. POPULATION EDUCATION/

7. FAMILY PLANNING PROGRAMS/

8. SEX EDUCATION

9. FAMILY PLANNING CENTERS/

10. TEACHING MATERIALS/

11. counsel $\$$ or debrief $\$$ or educat $\$$ or teach $\$$ or birth control $\$$ or family planning

12. 1 or 2 or 3 or 4 or 5 or 6 or 7 or 8 or 9 or 10 or 11

13. POSTPARTUM PROGRAMS/

14. PUERPERIUM/

15. POSTPARTUM WOMEN/

16. MATERNAL-CHILD HEALTH SERVICES/

17. MATERNAL HEALTH SERVICES/

18. postnatal $\$$ or post-partum or postpartum or postpartal $\$$ or puerperium

19. maternity or maternal or mother\$

20. 13 or 14 or 15 or 16 or 17 or 18 or 19

21. 12 and 20

\section{CINAHL, SliverPlatter (1982-200 I Oct)}

1. "Counseling"/ all topical subheadings / all age subheadings

2. "Sexual-Counseling"/ all topical subheadings / all age subheadings

3. "Patient-Education"/ all topical subheadings / all age subheadings

4. "Patient-Discharge-Education"/ all topical subheadings / all age subheadings

5. "Health-Education"/ all topical subheadings / all age subheadings

6. "Sex-Education"/ all topical subheadings / all age subheadings

7. "Health-Promotion"/ all topical subheadings / all age subheadings

8. "Teaching"/ all topical subheadings / all age subheadings

9. (counsel* or debrief* or educat* ${ }^{*}$ or teach*) in ti,ab

10. "Postnatal-Care"/ all topical subheadings / all age subheadings

11. "Postnatal-Period"/ all topical subheadings / all age subheadings

12. "Puerperium"/ all topical subheadings / all age subheadings

13. "Maternal-Health-Services"/ all topical subheadings / all age subheadings

14. "Maternal-Child-Health"/ all topical subheadings / all age subheadings

15. "Maternal-Behavior"/ all topical subheadings / all age subheadings

16. (postnatal* or post natal* or post-natal* or post-partum or post partum or postpartum or postpartal*) in ti,ab

17. (maternity or maternal or mother*) in ti,ab

18. puerperium in ti,ab

Education for contraceptive use by women after childbirth (Review)

Copyright @ 2012 The Cochrane Collaboration. Published by John Wiley \& Sons, Ltd. 
19. discharg* in ti,ab

20 . \#1 or $\# 2$ or $\# 3$ or $\# 4$ or $\# 5$ or $\# 6$ or $\# 7$ or $\# 8$ or \#9

$21 . \# 10$ or $\# 11$ or $\# 12$ or \#13 or \#14 or \#15 or \#16 or \#17 or \#18 or \#19

22. explode "Contraception"/ all topical subheadings / all age subheadings

23. explode "Contraceptive-Agents"/ all topical subheadings / all age subheadings

24. explode "Contraceptive-Devices"/ all topical subheadings / all age subheadings

25. explode "Family-Planning"/ all topical subheadings / all age subheadings

26. ((family near6 planning) or contracept* or (pregnan* near6 prevent*) or (birth near6 control*)) in ti,ab

27. \#22 or \#23 or \#24 or \#25 or \#26

28. \#20 and \#21 and \#27

\section{PsycINFO SilverPlatter (1899-200 I Oct)}

1. "Counseling-" in DE

2. "Sex-Education" in DE

3. "Client-Education" in DE

4. "Health-Education" in DE

5. "Health-Promotion" in DE

6. "Teaching-" in DE

7. (counsel $^{*}$ or debrief* or educat* $^{*}$ or teach $\left.{ }^{*}\right)$ in ti,ab

8. \#1 or \#2 or \#3 or \#4 or \#5 or \#6 or \#7

9. "Postnatal-Period" in DE

10. (postnatal* or post natal* or post-natal* or postpartum or post partum or post-partum or postpartal*) in ti,ab

11. (maternity or maternal or mother*) in ti,ab

12. puerperium in ti,ab

13. \#9 or \#10 or \#11 or \#12

14. explode "Birth-Control"

15. explode "Contraceptive-Devices"

16. "Family-Planning" in DE

17. explode "Sterilization-Sex"

18. (family near6 planning) or contracept* or (pregnan* near6 prevent*) or (birth near6 control*)

19. $\# 14$ or $\# 15$ or $\# 16$ or $\# 17$ or \#18

20. \#8 and \#13 and \#19

\section{SIGLE SilverPlatter (1980-200I Jun)}

1. (counsel* or debrief* or educat* ${ }^{*}$ or teach*)

2. postnatal ${ }^{*}$ or post natal* or post-natal ${ }^{*}$ or postpartum or post partum or post-partum or postpartal*

3. maternity or maternal or mother*

4. puerperium

5. \#2 or \#3 or \#4

6. (family near6 planning) or contracept* ${ }^{*}$ or (pregnan* near6 prevent*) or (birth near6 control*)

7. \#1 and \#5 and \#6

\section{ASSIA Bowker Saur CD-ROM (1987-200I Nov)}

1. $\mathrm{ft}=$ educat $\$$

2. $\mathrm{ft}=$ advice

3. $\mathrm{ft}=\mathrm{ad}$ vise $\$$

4. $\mathrm{ft}=$ debrief $\$$

5. $\mathrm{ft}=$ teach $\$$

6. $\mathrm{ft}=$ counsel\$

7. $c s=1$ or $c s=2$ or $c s=3$ or $c s=4$ or $c s=5$ or $c s=6$

Education for contraceptive use by women after childbirth (Review)

Copyright @ 2012 The Cochrane Collaboration. Published by John Wiley \& Sons, Ltd. 
8. $\mathrm{ft}=$ postpartum

9. $\mathrm{ft}=$ postnatal $\$$

10. $\mathrm{ft}=$ puerperium

11. $c s=8$ or $c s=9$ or $c s=10$

12. $\mathrm{ft}=$ pregnan $\$$ prevent $\$$

13. $\mathrm{ft}=$ contracept $\$$

14. $\mathrm{ft}=$ family planning

15. $\mathrm{ft}=$ abstinen $\$$

16. $\mathrm{ft}=$ birth control\$

17. $\mathrm{ft}=$ fertility regulat $\$$

18. $\mathrm{ft}=$ fertility control $\$$

19. $c s=12$ or $c s=13$ or $c s=14$ or $c s=15$ or $c s=16$ or $c s=17$ or $c s=18$

20. $c s=7$ and $c s=11$ and $c s=19$

21. $c s=7$ and $c s=11$

22. $c s=11$ and $c s=19$

\section{WHAT'S NEW}

Last assessed as up-to-date: 1 June 2012.

\begin{tabular}{l|l|l}
\hline Date & Event & Description \\
\hline 28 June 2012 & New citation required but conclusions have not changed & $\begin{array}{l}\text { New trials did not show evidence of effectiveness. } \\
\text { We assessed the quality of evidence (Data synthesis), } \\
\text { which included quality of intervention evidence (Table } \\
\text { 1) and then overall quality of evidence (Table 2). }\end{array}$ \\
\hline 30 May 2012 & New search has been performed & $\begin{array}{l}\text { Searches updated; two new trials included (Barnet 2009; } \\
\text { Katz 2011). }\end{array}$ \\
\hline
\end{tabular}

\section{H I S T O R Y}

Protocol first published: Issue 1, 1998

Review first published: Issue 4, 1999

\begin{tabular}{lll}
\hline Date & Event & Description \\
\hline 9 November 2009 & New citation required and conclusions have changed & $\begin{array}{l}\text { We had } 7 \text { trials to add. We excluded studies that had } \\
\text { issues regarding unit of analysis, i.e., 2 studies from } \\
\text { the original review (Foreit 1993; Sayegh 1976).Conse- } \\
\text { quently, the conclusions changed in this version. }\end{array}$ \\
\hline 25 June 2009 & New search has been performed & $\begin{array}{l}\text { New trials added (Bashour 2008; Black 2006; Gilliam } \\
\text { 2004; Proctor 2006; Quinlivan 2003; Saeed 2008). } \\
\text { O'Sullivan 1992 was moved to 'included studies,' due to }\end{array}$
\end{tabular}

Education for contraceptive use by women after childbirth (Review) 
defining postpartum education as that which occurred within 1 month of delivery. Added searches of clinical trial databases

15 June $2009 \quad$ Amended

21 May $2009 \quad$ Amended
Expanded time frame for postpartum education to include programs initiated in less than a month after delivery. Included use of health care services as an outcome

Authors added to lead update (LM Lopez, DA Grimes)

Converted to new review format.

\section{CONTRIBUTIONSOFAUTHORS}

\section{Original review}

J Hiller and E Griffith contributed to the preparation of the protocol. J Hiller, E Griffith, and F Jenner examined trials found after the literature search and the finalization of the original report. J Hiller and E Griffith abstracted data for the original review. J Hiller was responsible for the literature search, examination of literature used for background information, input of the data, and drafting the report through 2002.

\section{9 update and revision}

L Lopez reviewed the search results, conducted the primary data abstraction, incorporated the trials into the report, and drafted the revised manuscript. J Hiller provided input on the inclusion and exclusion criteria for trials and edited the manuscript. D Grimes conducted the second data abstraction, checked the data entry, and edited the manuscript. M Chen provided statistical consultation on cluster randomized trials.

\section{2 update}

L Lopez reviewed the search results, conducted the primary data abstraction, incorporated the trials into the report, and drafted the revised manuscript. M Chen reviewed the methods and interpretation of results. J Hiller reviewed the quality assessment information. DA Grimes identified another ongoing trial. All authors reviewed and commented on the manuscript. 


\section{DECLARATIONSOF INTEREST}

None known

\section{SOURCES OF SUPPORT}

\section{Internal sources}

- Adelaide University (JEH, through 2002), Australia.

- Health Services Research Unit, University of Aberdeen (JEH, 1997), UK.

\section{External sources}

- Cochrane Health Promotion and Public Health Field, Australia.

Support for conducting the review (JEH, through 2002)

- U.S. Agency for International Development, USA.

Support for conducting the review (LML, MC; DAG (2009 only))

- National Institute of Child Health and Human Development, USA.

Support for conducting the review (LML, MC; DAG (2009 only))

\section{NDEX TERMS}

\section{Medical Subject Headings (MeSH)}

*Contraception; *Patient Education as Topic; *Postpartum Period; Program Evaluation; Randomized Controlled Trials as Topic

\section{MeSH check words}

Adolescent; Adult; Female; Humans; Young Adult 